\title{
DE PLAATSING DER RAMA-RELIEFS VAN TJANDI LARA-DJONGGRANG EN DE ZONNE-OMLOOP
}

DOOR

Dr. W. F. STUTTERHEIM.

Het is een niet genoeg te herhalen waarheid, dat wij van de eigenlijke beteekenis der oudjavaansche bouwvallen, humne waarde voor de toenmalige wereld, hunne rol in het dagelijksch leven, zeer weinig afweten. Alle min of meer op intellectualistische sluitredenen geba. seerde gevolgtrekkingen daaromtrent, alie ,,verklaringen” van figuren der goden, helden, hunne indeeling aan den tempel, kortom datgene, wat zij voor den tijdgenoot waren, dat alles is weliswaar met veel vlijt en ijver loor ons, archaeologen bijeengezet en opgesteld, doch zou, indien de oudjavaansche priesters er kennis van kregen, hoogstens een medelijdenden glimlach op de lippen tooveren of een schouderophalen over zooveel onwetendheid en gebrek aan inzicht. Onze nitleggingen blijven hopeloos aan de oppervlakte en het is dan ook ongetwijfeld hierdoor, dat men zich somwijlen den ouden eeredienst van Java wil voorstellen als een op traditie berustend en daardoor geheiligd zinloos labyrinth, waarin de eigen priester verward raakte en waar ruimschoots gelegenheid was tot afdwalen van den geheiligden weg. Herhaaldelijk komt het voor, dat wij meenen te moeten constateeren een afwijken van wat wij als logisch systeem reconstrueeren en vooral bij het uitbeelden van godenfiguren of reeksen van voorstellingen ligt het dan voor de hand te denken aan een vergissing van den beeldhouwer; iets, waardoor tenminste de figuur van den priester gered blijft. Niettemin heb ik herhaaldelijk gelegenheid gehad zulk een meening te corrigeeren en aan te toonen, dat toch waarschijnlijk de vergissing niet aan hem, doch aan ons, archaeologen, moet worden toegeschreven en clat een en ander wel degelijk op logische wijze, doch dan volgens een ander, ons onbekend of slechts ten deele bekend denksysteem, zijn verklaring kan vinden. 
Rassers heeft in zijn Pandji-studie in het bijzonder gewezen op het feit, dat miskenning van dit denksysteem, van deze voorstellingswereld, die geheel anders was dan de onze, noodwendig fouten in de interpretatie der figuren en humne handelingen na zich moet sleepen en over het algemeen kan men zeggen, dat het doordringen in deze gedachtenwereld beter begrijpen met zich mede brengt. Wat nu de oudheden van Java aangaat, zoo zijn het voornamelijk de reliefvoorstellingen geweest, die telkens en telkens den interpretator tot wanhoop brachten angezien de voor ons gevoel logische indeeling der gebruikte stof menigmaal bleek te ontbreken en wij daarvoor in de plaats te maken kregen met een oogenschijnlijk geheel willekeurige verdeeling der tafereelen over de beschikbare ruimten.

$\mathrm{Nu}$ kan echter reeds de omstandigheid, dat zulke reliefs zijn aangebracht aan de heiligste bouwwerken van dien tijd, ons tot bijzondere voorzichtigheid manen en eenige berusting opleggen, voor het geval de aangetroffen verdeeling niet geheel klopt met hetgeen wij wel gaarne zouden gezien hebben. Een dergelijk geval doet zich voor bij de relieftafereelen van tjaṇ̣i Lara Djonggrang bij Prambanan. Talloos zijn de moeilijkheden, die aan de interpretatie daarvan in den weg gelegd waren. Om te begimnen treffen wij het Rāmaverhaal aan, verdeeld over twee van de drie voorhanden tempels en wel aan den Çiwa- en den Brahman-tempel, terwijl naar ons gevoelen juist de Wiṣnu-tempel de meest geschikte zou geweest zijn om met verhalen betreffende den Wị̣nu-awatāra Rāma versierd te worden. Çiwa-verhalen zouden wij aan den Çiwa-tempel hebben willen zien, doch, de eqrste figuur, die op de reliefs van dien tempel ontwaard wordt is Garuda en de tweede Wiṣnu zelf ! De conclusie ligt voor de hand: de priesters, die bij het ontwerpen hunne aanwijzingen gegeven hebben voor deze wonderlijke verdeeling, verstonden of hun vak niet meer, of zij namen het niet zoo nauw.

Dan bevalt ons ook de verdeeling der episoden niet al te zeer; sommige episoden zijn te lang gerekt, andere te kort of in het geheel niet vertegenwoordigd. Enkele zelfs werden wel als „, foutief” opgevat en door den interpretator verbeterd. Hier moest een mannefiguur een vrouw zijn, daar waren er te veel personen op één tafereel verzameld en leek het wel of twee Rāma's, twee Lakṣmaṇa's enz. door het bosch trokken, terwijl het dwaze van vele kleine onbegrijpelijke zaken terloops werd terecht gezet.

Het is mij mogen gelukken enkele van deze beeldhouwers-,,vergissingen" met behulp van maleische en javaansche populaire ver- 
tellingen en verhalen op hun juistheid te toetsen en daarbij bleek dat meestal de vergissing aan de zijde van den archaeoloog was geweest ${ }^{1}$ ). Tevens bleek, dat wij hier niet te maken hadden met het of ficieele Rāma-gedicht van den grooten dichter Vālmīki, dat steeds als origineel had gegolden voor de tallooze afwijkende Rāma-vertellingen ioor hecl Indië, maar dat wij een of anderen officieelen vorm van een dergelijke Rāma-vertelling voor ons hadden, die slechts in groote lijnen met het kunstdicht van den hofpoëet moet hebben parallel geloopen. Waarschijnlijk zelfs zou de inhoud van dergelijke afwijkende verhalen dichter bij het oer-Rāma-verhaal staan dan het laatstgenoemde. Helaas is het mij daarbij niet mogen grelukken de herkomst dezer afwijkende redacties aan te toonen, hoewel er redenen waren, die er mij toe brachten vooral het westelijk stuk van Indië als van bijzondere beteekenis voor de verbreiding van dergelijke verhalen over den archipel aan te zien. Niettemin is het afkomst-probleem der Hindu-cultuur op den archipel daarmede in een nieuw stadium gebracht en moet elke aanwijzing, hoe gering ook, opnieuw getoetst worden aan deze veranderde instelling, waarbij wij niet langer uitsluitend den blik gericht houden op het eerst veel later tot eenigen bloei van beteekenis geraakte Zuiden van Indië, doch op het Westen, en eventueel ook het Oosten, als doorgangsstations voor de groote, zich in het eerste duizendtal jaren van onze jaartelling buiten Indië uitstrekkende invloeden. Tot dergelijke aanwijzingen behoort ook hetgeen ik in de onderstaande regelen hoop uiteen te zetten.

De reeks van reliefpaneelen, die zich aan den binnenkant van de balustrade bevindt, welke rondom de ommegang van den Çiwatempel van Prambanan is opgesteld en welke nu, dank zij eenige herstelling, in de juiste belichting kan worden waargenomen, is op natuurlijke wijze door de vier trappen en portieken in vier gelijke of nagenoeg gelijke deelen verdeeld ${ }^{2}$ ). Volgen wij de door mij voorgestelde interpretaties van de afzonderlijke tafereelen, dan noteeren wij voor de eerste kwart-reeks de tafereelen vanaf de nederdaling van Wiṣn!ı tot en met den terugkeer van Rāma in Ayodhyā ${ }^{3}$ ), voor de tweede kwart-reeks de episoden vanaf de kroning van Bharata tot en met de ontmoeting met Çürpanakhāa ${ }^{4}$ ), voor de derde reeks vanaf den roof van Sìtā door Rāwaṇa tot en met de overwinning op Wâlin ") en voor de laatste reeks vanaf de beraadslagingen omtrent het zoeken naar de geroofde bruid tot aan den overtocht ${ }^{6}$ ).

Oogenschijnlijk is in deze verdeeling geen bijzonder systeem te 
ontdekken en in sommige gevallen, b.v. bij den roof van Sìtā worden naar ons gevoel de nauw samenhangende tafereelen van den gouden gazel en cien roof zelf op onaangename wijze door de trap onderbroken. In werkelijkheid kunnen wij echter wel degelijk een zeker systeem ontdekken in de verdeeling dezer reeksen over de vier vierdedeelen van den tempel. Het valt namelijk op, dat vanaf het oogenblik, waarop Rāma naar zijn kraton is teruggekeerd, tot aan dat, waarop hij te strijden had met Wãlin, een aaneengeschakelde reeks van tegenslagen zijn deel is. Heel de verbanningsgeschiedenis en die van den roof zijner echtgenoote valt tusschen deze twee punten. Daarentegen is alles, wat aan de tegenovergelegen helft van den tempel is afgebeeld van een beter en voor Rāma aangenamer gehalte; vanaf het begin tot aan den terugkeer is het één reeks van kleine en groote successen (uitverkiezing door Wiçwāmitra uit zijn broeders, het overwinnen van verscheidene daemonen, het winnen van zijn bruid en, last not least, het overwinnen van den voor hem gevaarlijksten tegenstander, die zijn eigen naam draagt, Rāmaparaçu). Terwijl de laatste kwart-reeks het begin geeft van een andere reeks van successen, die tot einddoel heeft het vinden van zijn bruid. Ware het toch niet geschied, dat Wālin de nederlaag leed, dan zou Sugrīwa nimmer den troon hebben kunnen beklimmen en Hanumat dus ook nimmer zijn uitgezonden en ten gevolge daarvan Sìtā ook nimmer zijn gevonden. De vier punten, waar de reeks door de trappen wordt onderbroken, blijken dus voor Rāma van het hoogste belang geweest te zijn en wel, de pradakșināa volgende: geboorte; toppunt van succes; verbanning; roof der bruid; gevecht met den gevaarlijken tegenstancler Wālin; verkrijgen van hulp; overgang op Langkā. Bezien wij deze markante punten nader, dan kunnen wij ze wederom in twee soorten splitsen en wel ten eerste de overgangspunten en ten tweede de keerpunten. Geboorte en roof zijn tot de eerste categorie te rekenen (de geboorte is een awatāra van Wiṣnu, dus slechts een overgang in een nieuw stadium), terwijl de terugkeer en de overwinning op Wālin respectievelijk de keerpunten zijn van succes in tegenslag en omgekeerd.

Deze verdeeling der verhaalstof kunnen wij nog eenig relief verschaffen door te letten op de ligging van de daarin een rol spelende markante punten. De geboorte ligt in het Oosten, het hoogtepunt in het Zuiden, de roof en tevens het eerste optreden van Rāwạ̣a, den aartsvijand, is in het Westen gelegen, terwijl in het Noorden de hernieuwde opgang een aanvang neemt. Welnu, lettende op het 
karakter dezer punten, geloof ik, dat wij ons niet te ver wagen, indien wij de overgangs- en keerpunten van Rāma’s loopbaan aan den Çiwatempel samen doen vallen met de zelfde punten in de zonnebaan. Het mag toch wel niet als een toevalligheid worden opgevat, dat Rāma's opgang, ondergang en opgang ten tweeden male, samenvallen met opgang, ondergang en opgang van de zon in haar dagelijksche baan, indien wij achtereenvolgens spreken van Oost-, Zuid-, West- en Noordpunt, of in haar jaarlijksche baan, als wij aannemen, dat hier gesproken moet worden van Lente-, Zomer-, Herfst- en Winterpunt. Vanaf het Oostpunt stijgt de Rāma-zon in haar baan op tot zij aan het Zuidpunt op het hoogtepunt is gekomen ${ }^{7}$ ); vervolgens daalt zij, hoewel nog krachtig, uit haar zonnehuis (het Zuidpunt = Ayodhyā) om in het Westpunt onder te gaan, d. w. z. haar strijd met de onderwerelddaemonen te aanvaarden, die haar van haar glans (Sìtā) beroofden ${ }^{8}$ ). Haar laagste punt bereikt zij in het Noorden, waar de laatste vijand overwomnen wordt (Wälin), doch tevens de hernieuwde opgang aanvangt. Ten slotte bereikt zij met hulp van goede onderwereldmachten den overwal en de nieuwe dag begint (op Langkā) ${ }^{9}$ ).

Hiermede is de eerste dag-gang van de Rāma-zon gesloten en vangt een nieuwe aan, die ik $\mathrm{U}$ echter in zijn beloop niet kan laten aanschouwen, aangezien de plaatsing der reliefs aan den Brahmantempel onzeker is en nog te veel ruimte laat voor twijfel ${ }^{22}$ ). Houden wij ons dus liever voorloopig aan den Çiwa-tempel.

Het zal den aandachtigen lezer niet ontgaan zijn, dat zich bij de toepassing van dit zonne-beeld op de opeenvolging der relieftafereelen eenige moeilijkheden voordoen, die schijnbaar niet met een en ander kloppen. Zoo zou men verwachten dat alles, wat zich ten oosten van het Zuidpunt bevindt, van een geregelden en ongestoorden opgang gretuigde. Niettemin zien wij vlak voor dat keerpunt een scene, die integendeel onheil roorspelt, nl. die van de kuiperijen van Kaikeyī. Zooals men weet heerschte ontrent de identificatie van dit tafereel eenige onzekerheid, zoodat wij hier misschien zullen mogen veronderstellen, dat de juiste interpretatie nog niet gegeven is ${ }^{10}$ ). Ik wijs daarbij echter op het feit, dat zulk een tafereel of tafereelenreeks, die vlak voor den overgang in een nieuwe kwart-reeks als het ware reeds met de volgende kwart-reeks in verband staat, geregeld is waar te nemen. In het Westen voorspelt de episode van den gouden gazel reeds den na den overgang komenden roof, in het Zuiden heeft het herstel van Sugriwa op den troon van Apenland reeds vóór den overgang naar het Oosten plaats en in het Oosten 
heeft de beeldhouwer, geheel tegen onze gevoelens in, op het laatst nog een stukje van Langkā gegeven, dat zwij voor den Brahmantempel zouden hebben gereserveerd.

Deze eigenaardigheid komt dus geregeld voor en behoort blijkbaar bij het gevolgde systeem, zoodat wij gerust mogen aannemen dat de interpretatie van het Kaikeyi-tafereel inderdaad juist is. Wij hebben hierbij waarschijnlijk te maken met een in de javaansche wereld nog steeds voorkomende gewoonte on de overgangen in verhalen en dergelijke zaken nimmer plotseling en onvoorbereid te doen plaats hebben ${ }^{11}$ ).

Een vraag, die ons, nu wij dus blijkbaar met een bepaalde opvatting inzake de verdeeling van het Rāma-verhaal over den tempel te maken krijgen, op de lippen komt, is de volgende. Is er dan in de verdeeling der paneelen ook niet een zekere regelmatigheid te ontdekken? Ik geloof, dat wij deze vraag bevestigend kunnen beantwoorden.

Zooals men weet is elk kwart-deel van de reeks verdeeld in zes paneelen, tezamen 24 paneelen uitmakende. Welnu, nemen wij een oogenblik aan, dat wij hier met de jaarlijksche zonnebaan te doen hebben, dan ligt het mijns inziens voor de hand om te veronderstellen, dat elk paneel een vier-en-twintigste deel daarvan verbeeldt; een halve maand dus of duidelijker gezegd een pakșa, aangezien de tijdrekening niet zoozeer uitsluitend met heele maanden als wel met pakșa's te werk ging. Helaas is het mij niet mogelijk daarbij een doorgevoerde verdeeling in çukla- en kṛ̣ṇa-pakșa's te ontclekken, hoewel dit in sommige gevallen zeker opgaat. Hierbij staat ons echter de onzuivere kennis van de waardeering dezer maandverdeeling in kosmisch verband in den weg, zoodat ons iets zal lijken te behooren tot een çukla-, wat den Hindu-Javaan als kṛ̣na zal zijn voorgekomen ${ }^{12}$ ).

Maar, misschien is het dan wel mogelijk de verdeeling nog verder door te voeren en kan uit de van de paneclverdeeling zoo sterk afwijkende tafercelverdeeing ook al het volgen van een bepaald systeem blijken. Een beslist antwoord kan ik ook op deze vraag niet geven, doch ik wil wijzen op het eigenaardige feit, dat het mogelijk is de paneelen van elke tempelhelft te verdeelen in 30 tafereelen, tezamen dus voor den geheelen tempel 60 tafereelen uitmakende, juist het aantal nādị̄'s van de dagelijksche zonne-tijdrekening ${ }^{23}$ )! Absoluut zeker is deze verdeeling echter nog niet, aangezien uit mijn 
pogingen tot scheiding der verschillende tafereelen duidelijk blijken kan, dat hier en daar nog speling mogelijk is, die niettemin zeker niet zoo groot is, dat het totaal getal belangrijk zou worden gewijzigd ${ }^{13}$ ).

Naast en door elkaar zouden dan aan dezen tempel (en dus ook aan (le twee andere tempels) de dagelijksche en de jaarlijksche zonnebaan in het Rāma-verhaal verwerkt zijn en het is duidelijk, dat een dergelijke systematische verdeeling van de verhaalstof over de beschikbare oppervlakte menig bezwaar, dat tevoren tegen deze verdeeling werd geopperd, kan opheffen: daar, waar naar onze opvatting teveel van de eene, te weinig van de andere episode werd gegeven, zal het systeem den beeldhouwer tot diens keuze gebracht hebben en afwijking van dat systeem zullen wij van hem zeker niet mogen verwachten. Even duidelijk is het echter, dat wij hier te maken hebben met iets, wat aan de eene zijde nauw verband houdt met de wajangvertooningen van heden, aan den anderen kant daarvan weer belangrijk afwijkt. Voor het eerste kunnen onze gegevens dus de kracht van Brandes' opmerkingen over het oost-javaansch karakter van tjaṇ li Lara Djonggrang aanmerkelijk versterken ${ }^{14}$ ): wat wij hier voor ons zien, is in zekeren zin niet anders dan een twee (drie-) daagsche wajangvertooning, waarbij, evenals nu, de inhoud van het vertoonde verhaal, naar de mate het uur vordert, verschillende stemmingen bij het publiek dient op te wekken. Vreugdevol is de stemming van den ochtend tot aan het middlaguur; verontrust tot aan zonsondergang; treurig tot aan middernacht ${ }^{15}$ ), doch wederom hoopvol tot aan den morgenstond, waarna, gedurende de vertooning van den tweeden dag, de hoopvolle stemming zal zijn overgeslagen in de vreugdevolle van het begin van den eersten dag.

Voor het laatste moet ik echter opmerken dat, voorzoover de bouw van de lakon betreft, aanmerkelijke verschillen zijn op te merken, en wel voornamelijk dit, dat de held van het verhaal hier klaarblijkelijk niet, zooals door Rassers voor Indonesië is aangetoond, een maan-held is, doch een zonne-held. Een verschil tusschen Nidden- en Oost-Java, dat parallel loopt aan de vele door mij elders gesignaleerde tegenstellingen tusschen de kunstopvattingen van beide cultuurcentra.

In verband met dit laatste zou ik dan ook nog even willen terugkeeren tot hetgeen ik in het begin van bovenstaande regelen heb opgemerkt, namelijk dat het ons bevreemdt het Rāma-verhaal aan 
den Çiwa-tempel afgebeeld te zien. Hoezeer ook het ontdekken van een streng systeem, dat bij de verdeeling van de verhaal-stof is gevolgd, ons zal kunnen verzoenen met verschillende eigenaardigheden, die ons eerst vreend leken, toch zal het ons met de bedoelde merkwaardigheid niet accoord kunnen doen gaan. Het komt mij echter voor, dat ons hierbij de toepassing-zonder-meer van het in de nieuwere indische literatuur gebezigde stel van tien Wiṣnu-awatāra’s op Java in den weg staat. Immers, wij hebben reden om aan te nemen, dat de reeks in den tijd van tjaṇdi Lara Djonggrang een geheel andere was ${ }^{16}$ ). En daarmede houdt ten nauwste verband de positie, die Wiṣnu zelf in de trimūrti inneemt.

Daar, waar men de in later tijd eerst op tien gebrachte reeks van awatāra's kent, wordt Wiṣnu als hoogst principe en Algod vereerd, naast en zonder veel innerlijk verband met de nevenfiguren uit de trits. Wij mogen echter veronderstellen, dat op Java, conform aan hetgeen wij uit de buddhistische geschriften en de huidige balische praktijk weten, deze trits eer moet worden opgevat als een dricvoudige verschijningsvorm van een Hooger Wezen en dat hoogere wezen was de Zon. Waar nog steeds op Bali Soerja de essence is van het Al, waar Siwa, Wisnoe en Brahma daarvan niet meer zijn dan verschijningsvormen, waar de soerjasewana, letterlijk de .,Zonnevereering", op Bali de vereeringsceremonie is kat' exochèn ${ }^{17}$ ), waar in het buddhistisch systeem van de Sang Hyang Kamahāyānikan, dat zeker voor den tijd van tjandi Lara Djonggrang zal hebben gegolden, de verbindingsschakel met het Çiwaisme wordt gevormd door de godentrits van dien godsdienst (lees: secte) te doen emaneeren uit den dhyānibuddha met het sterke zonnekarakter: Wairocana ${ }^{18}$ ) en waar, ten slotte, de midden-javaansche periode onder sterken invloed heeft gestaan van de soematraansche buddhistische leerstellingen der Çailendra's, wier rijk waarschijnlijk op zijn beurt den invloed moet hebben gevoeld van dat van koning Harșawardhana, den zoon van Rājyawardhana, den ,Zonnevereerder”, daar mag ons zulk een zonne-beteekenis, als ons nu duidelijk uit de reliefs van tjandi Lara Djonggrang voor de oogen treedt, niet al te zeer verbazen ${ }^{19}$ ).

Ja, wij mogen zelfs veronderstellen, dat het kiezen van juist dit verhaal zal bepaald geweest zijn door de rol, die de vorst, wiens tempel wij hier behandelen, als zonne-incarnatie te spelen had. Zoo zou het kunnen geweest zijn als het ware de levens-lakon van dien koning. wiens magisch contact met de levenden door midlel van 
dezen tempel kan zijn te werk gesteld en zou het afgebeelde verhaal hebben volgezeten met echt-javaansche toespelingen op hetgeen in zijn leven gebeurd was; zoo dit al waar kan zijn, zou toch de sleutel (laartoe ons wel immer blijven ontbreken ${ }^{20}$ ). En zoo zou hier, evenals in Oost-Java het Pandji-thema in de geschiedschrijving tot Leitmotiv is geworden, het Rāma-thema dezelfde rol hebben gespeeld; in wezen zijn beide thema's verwant, in uitwerking echter verschillend. Nog steeds is het een veel voorkomende gewoonte onder Javanen zoowel als Baliers, om zich een bepaalde figuur uit de wajangverhalen te kiezen tot Leitmotiv voor het leven; in Siam heeft dit de of ficieele uitdrukking gevonden in den vorstentitel Ramā en ook daar leeft ieder vorst zijn Rāma-tragedie ${ }^{21}$ ).

Doch wij raken op dwaalwegen en loopen gevaar de feiten uit het oog te verliezen; hypothesen zullen eerst op het boven verschafte materiaal opgebouwd kunnen worden, indien het op zijn wèrkelijke waarde is getoetst. Zooveel is echter wel als zeker aan te nemen, dat cle reliefverdeeling aan tjaṇ̣i Lara Djonggrang geen willekeurige is, doch dat integendeel een streng systeem, dat van de zonnebaan, in acht is genomen. Misschien kunnen anderen hierop verder weven an het herstel van het kosmisch weefsel, dat in den midclenjavaanschen tijd over de tempels moet gelegd zijn geweest.

Soerakarta, 15 November 1927.

\section{AANTEEKENINGEN.}

1) Rāmalegenden und Rāmareliefs in Indonesien, München 1925.

2) Krom, Inleiding tot de Hindoe-Javaansche Kunst, I: $453 \mathrm{vlg}$.

3) Rāmalegenden II: pl. 2-16. Voor de interpretatie zie I: 148-151.

4) O.c. II : pl. 17-33. Voor de interpretatie zie I: 152-161.

5) O.c. II : pl. 34-51. Voor de interpretatie zie I: 161-169.

6) O.c. II : pl. 52-65. Voo: de interpretatie zie I: 170-173.

i) De Garuḍa-zonilevogel opent de reeks.

s) Merkwaardig zijn de verlossingscenes in dit kwartdeel (o.c. II: pl. 36 en 37), daar de ondergaande zon in het oude stelsel op haar onderwereld-reis inderdaad als verlosser optrad van de aldaar smachtende zielen, die, door haar te helpen, het geluk deelachtig werden met haar de bovenwereld te bereiken (vgl. Egypte). Deze en dergelijke interpretaties houden natuurlijk niet verband met le systcmatische verdceling der reliefs, wèl met een zonmekarakter van het Rāna-verhaal, welke twee zaken wij goed van elkaar dienen te scheiden.

9) Mijns inziens is het naar voren tredend daemonisch karakter der apen- 
figuren, dat in later tijd zeer evident zal worden, misschien als onderwereldkenmerk op te vatten. De rākṣasa's zijn zeker geen onderwereldmachten, want hun Heer, Rāwaṇa, lijkt mij eerder een tegenhanger van Rāma te zijn, die bij diens ondergang opgaat (Westpunt van den tempel van (Ciwa) en bij diens opgang ondergaat. Een maanfiguur dus? Maar dat strijdt met het geheele karakter van den daemon. Zulke vragen zullen, indien zij tot oplossing gebracht worden, er veel toe kunnen bijdragen te onderkennen in hoeverre het zonne-systeem als mythische legende levend gevoeld en verwerkt werd. Helaas staat ons hierbij de geschonden toestand van den Brahman-tempel in den weg.

10) Rāmalegenden I : 151 vlg. Ii : pl. 16.

11) Vgl. de gewoonte $\mathrm{cm}$ in het laatste stuk van een voorafgaanden zang op den volgenden zang te zinspelen. Overigens is deze gewoonte, om scherpe tegenstellingen en plotselinge wendingen zooveel mogelijk te vermijden, niet alleen Javaansch, doch typisch te achten voor elke niet-moderne gedachtenwereld, waarbij zij te sterker optreedt, naarmate de overblijfselen van een het geheele maatschappelijke en private leven omvattend systeem krachtiger of zwakker zijn waar te nemen. In sommige gevallen (en daar behoort zeker het javaansche toe) is deze houding tot in de perfectie doorgevoerd en bevat dientengevolge het onderkennen daarvan een der allervoornaamste lessen voor het goed verstaan van een dergelijke maatschappij.

1:2) Ook hier weder geldt hetgeen boven werd opgemerkt, namelijk dat b.v. het eventueel blootleggen van sporen van een zodiak-verwerking in de verschillende paneelen niet zoozeer den tempel, als wel het verhaal raakt. Hoogstens kan het verband houden met het pasklaar maken van het Rāma-verhaal voor den tempei. In dat opzicht is het dan ook wel doenlijk groepen van twee bij elkaar behoorende reliefpaneelen te vormen, hoewel zich hier en daar moeilijkheden voordoen.

13) Aangezien deze tafereel-verdeeling niet, zooals met de paneel-verdeeling het geval is, vanzelf volgt uit hetgeen de bouwkundige indeeling van den tempel te zien geeft, laat ik hier een korte omschrijving volgen. Het romeinsche cijfer cluidt een paneel, het arabische een tafereel aan.

I : $1=$ Garuda's vereering.

I: 2 = Wiṣnu voor de vorsten.

I: $3=$ Hofhouding van Daçaratha.

II : $4=$ Bezoek van Daçaratha aan Wiçwāmitra.

II : $5=$ Zonen van Daçaratha voegen zich bij Wiçwāmitra(?).

III : $6=$ Rāma doodt Tāṭakā.

IV : $7=$ Offer van Wiçwāmitra.

IV : $8=$ Rāma doodt daemonen.

$\mathrm{V}: 9=$ Rāma bij Janaka.

$\mathrm{V}: 10=$ Rāma schiet.

VI: $11=$ Terugtocht met Sitā.

VI : $12=$ Ontmoeting met Paraçurāma.

VI : $13=$ Rāma overwint Paraçurāma.

VI $: 14=$ Kuiperijen van Kaikeyī.

VII : $15=$ Kroning van Bharata.

VII : $16=$ Kroningsfeestelijkheden.

VII $: 17=$ Daçaratha treurt on Rāma.

VII $: 18=$ Uittocht van Rārna enz.

VIII $: 19=$ Verbranding van Daçaratha.

VIII : $20=$ Uitdeeiing van geschenken aan de armen.

IX : $21=$ Bharata zockt Rāma. 
IX : $22=$ Bharata voor Rāma.

$\mathrm{X}: 23=$ Rāma trekt de wildernis in.

$\mathrm{X}: 24=$ Rāma doodt Wirādha.

$\mathrm{XI}: 25=$ Scene in het woud.

$\mathrm{XI}: 26=$ Rāma schiet den vogel blind.

XII $: 27=$ Tweede scene in het woud.

XII $: 28=$ Komst van Çūrpaṇakhā.

XII : $29=$ Çūrpaṇakhā voor haar broeder.

XII $: 39=$ Scene van den gouden gazel.

Zooals men ziet, zou hier en daar een kleine wijziging kumnen worden aangebracht, die twee tafereelen kan bijeenvoegen of een tafereel in tweeën spiltsen. Waar echter, hoe mnen dit ook doet, het totaal de clertig ten nauwste nabijkomt, meen ik dat een verdeeling in dertig niet tot de onmogelijkheden behoort. De derde en vierde kwart-reeks geven iets meer moeite.

XIII : 31 = Rāwaṇa rooft Sītā.

XIII : $32=$ Gevecht met Jāțāyus.

XIII : 33 = Jāțāyus voor Rāma.

XIII : 34 = Rāma doodt Kabandha (eerste verlossingsscene).

XIV : $35=$ Tocht door het woud.

XIV: $36=$ Rāma doodt de krokodil (tweede verlossingsscene).

$\mathrm{XV}: 37=$ Ontmoeting met de apen.

$\mathrm{XV}: 38=$ Afscheid van de apen.

$\mathrm{XVI}: 3^{*}=$ Dorstscene.

XVI : $40=$ Lakṣmaṇa haalt water.

XVI : $41=$ Ontmoeting met Sugriwa.

XVII : $42=$ Krachtproef.

XVIII: $43=$ Eerste gevecht met Wālin.

XVIII: $44=$ Tweede gevecht met Wālin.

XVIII : $45=$ Herstel van Sugriwa op den troon.

XVIII : $46=$ Apenfeest (banjolan?).

XIX $: 47=$ Tocht naar de kust.

XIX : $49=$ Beraadslagingen.

XIX : $49=$ Bevel tot uitrukken van de troepen.

XIX: $50=$ Apensceine (banjolan :).

XX: $51=$ Hanımat op Langkā.

$\mathrm{XX}: 52=$ Hanumat vindt Sitā.

XXI: $53=$ Hanumats staart in brand gestoken.

XXI : $54=$ Hanumat steekt met zijn staart Langkā in brand.

XXII : 55 = Verslag van Hanumat aan Rāma.

XXIII : $56=$ Rāma dwingt den zeegod te komen.

XXIII: $57^{\circ}=$ De zeegod verschijnt.

XXIV: $58=$ Dambouw.

XXIV:59 = Verwoesting van den dam door de visschen.

XXIV: $60=$ Overtocht.

Intusschen moet worden opgemerkt, dat bij de boven gegeven verdeeling een zekere onregelmatigheid ontstaat. Men krijgt namelijk aan de oostelijke helft van den tempel $2 \times 14$ tafereelen en aan de westelijke helft $2 \times 16$ tafereelen. Mocht het gelukken voor beide helften een reeks van 15 tafereelen te verkrijgen, zoo zou een gelijkmatige verdeeling ontstaan. Bij de onzekerheid, watrin echter het geheele vraagstuk nog verkeert, is het zaak hier voorzichtig- 
heid te betrachten, aangezien een dergelijke verdeeling in ongelijksoortige helften misschien in het systeem kan behooren.

14) T. B. G. XLVII : 414 vlg.

15) Ik wijs terloops op het „Rama gandroeng”, zooals dat in de Serrat Rama van Jasa di Poera zoo sterk naar voren treedt gedurende een dezer afdeelingen van het verhaal.

16) Krom, Inleiding enz. I : 97 zegt namelijk : „Het oorspronkelijk onbepaalde getal dezer awatāra's is later op tien gefixeerd, waarvan de meeste ook op Java teruggevonden zijn".

Hieruit blijkt dat de schrijver een reeks van tien op Java verwacht en dus ook een Wișṇu, in de positie van den in Indië aan deze reeks verbonden Algod. Ten rechte zijn er tot nog toe op Java slechts zes uitbeeldingen van awatära's aangetroffen en wel de warāha-, ṇ̣singha-, wāmana-, paraçurāma-, rāma- en kṛș̣nāwatāra.

Van de overige, matsya-, kurma-, buddha- en kalkyawatāra zijn geen met zekerheid te herkennen afbeeldingen overgebleven. De sluitsteen van tjandi Sawěntar (O. V. 1922: fig. 11) is als een zonnevoorstelling op te vatten (Djawa 1926: 338) en kan dus geen Kalkyawatāra zijn. Het zoogenaamde ,karnen van den Oceaan", zooals dat zou zijn uitgebeeld in het bekende reliefwerk van Sirah Kĕntjong en langs een omweg dan een voorstelling van de kūrmāwatāra zou kunnen geven, is ten rechte een geheel andere voorstelling (Djawa 1926: 336), terwijl van de beide andere nimmer eenig spoor is te ontdekken geweest (Vgl. nog Drewes, Drie Javaansche Goeroes enz. pag. 153, 154).

Bezien wij daarenboven eens, wat de resten van tjaṇdi Lara Djonggrang omtrent de daar gegolden hebbende awatāra-reeks kunnen zeggen, dan blijkt dat in of aan den Wiṣnu-tempel zich moeten bevonden hebben vier uitbeeldingen van den god en wel een als wāmanāwatāra, een als warāhāwátāra, een als nụsinghāwatāra en dan ten slotte het hoofdbeeld. Dat er niet meer vormen tegenwoordig waren, kan blijken uit het feit, dat ook in den Brahman- en den Çiwatempel de daar vereerde goden viermaal waren vertegenwoordigd ( $\mathrm{Krom}$, Inleiding I : $482 \mathrm{vlg}$ :) ; bij de aan de tjanḍi zoo duidelijk gemanifesteerde stelselmatigheid en symmetrie zou iets anders niet te verwachten zijn. Intusschen vestig ik er de aandacht $\mathrm{cp}$, dat wij hier slechts te maken hebben met vereeringsbeelden van drie wiṣnwawatāra's, terwijl de drie overige van het aan de tjaṇ̣i te vinden stel op geheel andere wijze hun uitbeelding hebben gevonden: Kṛșna en Rāma weliswaar minder officieel dan de drie genoemde, Paraçurāma zelfs beduidend minder en als terloops in het Rāma-verhaal.

Een en ander duidt in geen enkel opzicht op een in dien tijd gevolgde reeks van tien awatāra's, integendeel, eerder op een reeks van vijf of hoogstens zes, waarbij de laatste drie (Paraçurāma, Rāma Dāçarathi en Kṛ̣ṇa) van minder beteekenis waren dan de eerste drie (warāha-, wāmana- en nṛsinghāwatāra).

Gaan wij nu de ontwikkeling van het awatära-leerstuk in Indië na, dan treft het ons, dat daar oorspronkelijk een veel kleiner getal wordt opgegeven, waarbij de reeks zou bestaan hebben uit juist dezelfde als wij voor Java konden noteeren (Mahābhārata XII: 349, 37). Later breidde die reeks zich uit (Hemacandra Raycaudhuri, Materials etc. 105 en Bhandarkar, Vaiṣnavism etc. 41,42$)$.

17) Zie vooral Goris, Oud-Javaansche en Balineesche theologie, pag. 9 vlg. en in het bijzonder pag. 11, waar wij lezen: ,... de allerbelangrijkste en het meest herhaalde mantra uit de geheele Balineesche liturgie: de „Kūța-mantra”, het spits-formulier: „Oṃ hrāṃ hrị̣̄ sah paramaçizuādityāya namah”. Lof den allerhoogsten Çiwa-Zon".

D1. 84. 
18) Sang Hyang Kamahāyānikan, uitgave Kats, aanhangsel I.

19) Rāmalegenden enz. I: 211 vlg. Wat de eventueele indische invloeden betreft, zoo wil ik er nog op wijzen, dat bij de Saura's een secte, die blijkens de oorkonden ook op Java moet hebben bestaan (Bosch in T. B. G. LIX: 510) en die door hun naam (zonnevereerders) het zonnekarakter van hun opvattingen verraden, de zon in haar dagelijksche baan vereerd werd als Brahman bij den opgang, als Çiwa in haar hoogtepunt en als Wiṣnu bij haar ondergang. Bij hen was Rām. de meest gelieíde held (Bhandarkar, o.c. 152).

Er bestonden echter nog meer zonne-vereeringen; zoo behoorde de boven vermelde vader van Harșawardhana tot de aanhangers van een cultus, welke terugging of een oud-perzische zonne-vereering, die speciaal gevonden werd in westelijk Indië, van Gujarāt tot Multān (Bhandarkar, o.c. 155). Dit kan ons in verband met de veronderstelde invloeden via westelijk Indië in het jijzonder interesseeren (Zie ook Jahn, Das Saurapurāṇam, XX: „Persische Einflüsse sind nicht ausgeschlossen"). Ik wijs in dit verband op mijn gissing omtrent het vaderschap vaı Rāma over Hanumat (Rāmalegenden I: 95, 96).

Ouder dan de boven genoemde zonne-vereeringen is wel die, waarvan in de upaniṣads sprake is (Kauṣitakibrāhmaṇopaniṣad) en waarin de zon des ochtends, des middags en des avonds met bloemen en water werd vereerd. Speciaal op Bali spelen bloemen en wijwater bij het soerjasewana een groote rol (Bhandarkar, o.c. 151, De Kat Angelino, Mudra's op Bali, passim, Goris, o.c. passim).

De Kat Angelino vond op Bali in een sangoepati (verklaard als te bestaan uit sangoe en pati, dus: leeftocht voor den dood, doch waarschijnlijk afgeleid van sanskrit samutpatti) de aanroeping van Soerja en Tjandra tegelijk met een aanduiding omtrent een lang leven. Zulks zal ongetwijfeld samenhangen met de indische gewoonte, waarbij tijdens de investituur met het koord de guru zich tot de zon wendt met verzoek om lang leven voor zijn çișya. De overeenkomst springt te meer in het oog, als wij bedenken dat de sangoepati een formule is, die voorkomt op de achterzijde van de panoegraha, het diploma voor den volleerden priesterleerling (De Kat Angelino, o.c. 28).

20) De vraag of tjandi Lara Djonggrang een bijzettingstempel zou geweest zijn, is nog steeds niet opgelost. Ik wil hier slechts dit bij opmerken, dat het ontbreken van de asch van den bijgezetten vorst niet behoeft te wijzen op het tegendeel. De asch zal ook in dien tijd wel naar zee zijn gebracht of door middel van een rivier daarheen gedreven. Bijzetten zal niet hetzelfde beteekend hebben als wat wij daar onder verstaan en het gebruik van „tjaṇụi”, „tjinaṇụi” op Bali wijst erop, dat hier eerder andere stoffen (lijkwater enz.) in den grond werden begraven, waarop dan een bouwwerk werd geplaatst. $(V . d$. Tuuk, Wdbk. I : 566). Waarschijnlijk moeten wij dus vóór alles denken aan een plaats van magisch contact na den dood van den verbranden vorst; later hoop ik daar uitvoeriger op terug te komen.

21) Döhring, Siam. I : 36.

$\left.{ }^{22}\right)$ De Heer de Haan, die thans bezig is met pogingen, voornamelijk op grond van gegevens van bouwkundigen aard (inkappingen, sponningen enz.) de losse reliefpaneelen van den Brahman-tempel een plaats toe te wijzen, komt daarbij tot het volgende beloop: van Oost tot Zuid het oprukken tot en met het gevecht van Rãma en Indrajit; van Zuid tot West de episodes van Kumbhakarṇa tot en met de hereeniging van Rāma en Sïtā; van West tot Noord de verstooting tot en met Sìtā's verblijf bij Wālmìki en van Noord tot Oost het slot van het verhaal.

Men zal opmerken, dat hier het hoogtepunt (overwinning op Rāwaṇa, her- 
eeniging met Sìtā) in het Westen ligt, hetgeen schijnbaar een afwijking is van hetgeen in den tekst omtrent den Çiwa-tempel werd opgemerkt. In verband met in het vervolg van dit artikel op te merken onderverdeelingen, zal hieraan deze beteekenis niet behoeven te worden gehecht. Ik kom hier dan ook straks nog ap terug.

${ }^{23}$ ) In verband met de verdeeling in 30 tafereelen, waartoe de heer de Haan bij zijn reconstructie-pogingen van de reliefreeks aan den Brahman-tempel meent te moeten komen, moet ik hier in herinnering brengen, dat boven in een noot werd gewezen op de eigenaardigheid, dat hier (aan den Brahmancempel) het hoogtepunt in het Westen is gelegen. Waar de Çiwa-tempel haar reliefreeks in 60 tafereelen laat verdeelen en de Brahman-tempel slechts in 30 (met behoud van 24 paneelen), daar dienen wij dus den omloop van den Brahman-tempel te beschouwen als half de omloop van den Çiwa-tempel; doch daarmede verschuiven dus de windstreek-punten en vertegenwoordigt de Brahman-tempel slechts een halve dag. Misschien zal de andere helft opgeleverd zijn door den Wiṣnu-tempel. Het geheel zou dan een twee-daagsche lakon zijn met twee opeenvolgende awatāra's. Bij deze verdeeling wordt het ook duidelijk, waarom de scheiding tusschen de reeksen op het Zuid-punt zooveel minder uitgesproken is bij den Brahman-tempel, dan bij den Çiwa-tempel: op dat punt is men nog lang niet aan het hoogtepunt van het verhaal toe en behoort men dus een vlotten overgang te hebben naar de rest van den OostZuid-gang. Intusschen, een scheiding moet er zijn, en wel voor de paneelverdeeling. $\mathrm{Zij}$ is er dan ook inderdaad, maar niet door het in de reeks brengen van een trap-portaal, slechts van een ornament-paneel. 


\section{EEN EN ANDER OVER PIETER LINTGENS.}

DOOR

DR. J. W. IJZERMAN.

Met Aanteekeningen en Bijlagen.

Het octrooi der Vereenigde Oost-Indische Compagnie had aan haar, met uitsluiting van alie anderen in de Republiek der Vereenigde Nederlanden, het recht gegeven van den handel op Oost-Indië. Wie dus buiten haar aan dien handel wilde deelnemen, moest elders de gelegenheid zoeken. Van daar reeds kort na haar oprichting pogingen om samen te werken met Hendrik IV, Koning van Frankrijk, die vurig wenschte in zijn land een groote handelsonderneming op Indië te vestigen en die begreep, dat de ervaring op verschillende reizen in de Nederlanden opgedaan, hem daarbij van groot nut kon zijn. De kooplieden, met wie hij achtereenvolgens tot dit doel in aanraking kwam, waren Balthasar de Moucheron, Pieter Lintgens en Isaäc le Maire. De minst begaafde van deze drie was zonder twijfel Lintgens; hij is dan ook verreweg de minst bekende. Het verloop der Fransche hemoeiïngen in de eerste jaren der zeventiende eeuw om steun van de Generale Staten te verkrijgen wordt door De Jonge in Deel III van zijn „Opkomst van het Nederlandsch gezag in Oost-Indië” op voortreffelijke wijze geschetst. Voor zoover Lintgens daarin betrokken was, maakte hij (De Jonge) gebruik van de briefwisseling, welke gevoerd werd tusschen den Franschen gezant in de Nederlanden Paul Choart, seigneur de Buzanval, en den minister Nicolas III de Neufville, seigneur de Villeroi. Zoo kon hij Lintgens in 1605 ten tooneele voeren als een reeds bejaard, zeer vermogend ${ }^{1}$ ) koopman, vurig Doopsgezinde, die op gelukkige wijze zijn persoonlijk belang in overeenstemming wist te brengen met zijn godsdienstige overtuiging. Uit andere bron stamt zijne mededeeling, dat Lintgens weinig tijds, nadat zekerheid omtrent de mislukking van zijn plan was verkregen, alzoo kort na Juli 1606, zou overleden zijn. ${ }^{2}$ ) Een voorloopig onderzoek heeft evenwel aangetoond, dat de voorstelling als zou Lintgens in 1605

1) De Jonge, D1 III, 1865, p. 117.

2) Ibid, p. 119. 
een groot vermogen hebben gehad, evenmin juist is, als de vermelding van zijn overlijden in het volgende jaar. ${ }^{1}$ )

Van Lintgens' hand is geen geschrift bewaard gebleven. Zijn leven is slechts ten deele bekend; zijn doen en laten vóór zijn veertigste jaar ligt grootendeels in het duister. Maar uit verschillende bronnen, het Oud Notarieel en andere archieven van Amsterdam en de Sententiën van het Hof van Holland verneemt men, dat hij ruim zijn deel had aan de groote moeilijkheden, waarmede een koopman en reeder, die op eenigszins uitgebreide schaal zaken wenschte te doen, in het eind der XVIde en het begin der XVIIde eenw te kampen had. Daar leert men hem kennnn als een zeer ondernemend, maar weinig scrupuleus man; als iemand, dien het niet altijd voor den wind ging en die langen tijd het hoofd boven water wist te houden, maar ten slotte met finantieelen ondergang eindigde.

Hij was uitgeweken uit de Zuidelijke Nederlanden, geboren in of omstreeks $1540 .{ }^{2}$ ) Het is niet bekend, wanneer hij zich te Amsterdam gevestigd heeft, waar zijn geloofsgenooten, de vredelievende Doopsgezinden, aanvankelijk niet als volgerechtigde burgers werden aangezien. Na de alteratie in 1578 werden zij niet dadelijk tot het poorterschap toegelaten, omdat zij den daartoe gevorderden eed weigerden af te leggen, en met een belofte geen genoegen werd genomen. Tien jaar later ontvingen zij een afwijzende beschikking op hun verzoek om in het openbaar in kerken te mogen prediken en moesten zij zich cvenals de Lutherschen, voor hun bijeenkomsten tevreden stellen met particuliere huizen of schuren. ${ }^{3}$ ) Toch was hun aantal niet gering, en vormden zij binnen korten tijd een welvarende gemeente, wier leden niet weinig tot de ontwikkeling en den bloei van Amsterdam's handel hebben bijgedragen.

Lintgens was gehuwd met Elsgen Bartholomeusdr. Dit echtpaar had vier zoons, Hendrik (geb. in 1567), Pieter, Aernout en Salomon, benevens twee dochters Margaretha en Susanna, ${ }^{4}$ ) en woonde in het huis ,de Wildeman” in de Warmoesstraat.

1) Zie ook de in dit opzicht onjuiste voorstelling in Bakhuizen van den Brink's „Studiën en Schetsen over Vaderlandsche Geschiedenis en Letteren”, IV, den Haag 1877 , p. $248,252$.

2) In 1595 was hij omstreeks 55 jaar oud, volgens zijn verklaring op 17 Augustus 1595 voor notaris J. Gijsberts. In den brief van burgemeesters van Amsterdam naar Genua gezonden op 12 Juni 1609, wordt gezegd, dat hij toen over de 70 jaren oud was, maar men wilde toen den indruk vestigen, dat hij geholpen moest worden.

3) Jan Wagenaar, Amsterdam 1760. D1. p. 365, 404.

4) Zie Bijlage $I$. 
Uit verschillende aanteekeningen, waarvan de oudste dateert van 1582, blijkt, dat hij te Amsterdam als koopman, reeder en assuradeur werkzaam was en groote zaken deed. Hij had factoors in Middelburg, Antwerpen, Dantzig, Malaga, Sevilla, Lissabon, Genua en mogelijk nog in andere plaatsen. $\mathrm{Zijn}$ naam wordt bij verschillende ondernemingen met de beste van Amsterdam genoemd. Hij is zeker aandeelhebber geweest in de eerste uitrusting van de Compagnie van Verre, hoewel de grootte der door hem ingelegde som niet bekend is. Zijn zoon Aernout ${ }^{1}$ ) maakte de eerste reis naar Oost-Indië als adelborst mede. Bij het vertrek uit Texel op 2 April 1595 was deze 23 jaar oud.

In de tweede helft van hetzelfde jaar 1595 sloot Lintgens voor den notaris J. F. Bruyningh te Amsterdam niet minder dan 21 contracten van bevrachting af met schippers, die zouden varen op Portugal en Spanje. Blijkbaar was hij noch door de inbeslagneming der Nederlandsche schepen in April, noch door de verbodsbepalingen tegen den uitvoer van granen naar vijandelijke havens, afgeschrikt.

In het najaar van 1596 vindt men de uitzending van drie schepen met gelijke bestemming bij denzelfden notaris vermeld.

Te midden van deze groote bedrijvigheid werd Lintgens overvallen door de aanbieding van een aantal wissels tot een gezamenlijk bedrag van f 39.373 , die hij niet kon betalen. Kennelijk was hij vastgeloopen. Tot een faillietverklaring ${ }^{2}$ ) kwam het echter niet. Hij wist zijn schuldeischers door overlegging van een staat zijner crediteuren 30 November 1596 tot een langzame afwikkeling hunner belangen te bewegen, waarbij hun $8 \%$ interest over het hun toekomende zou worden berekend. Zijn boekhouder Jaques Mandekens bewees hem daarbij goede diensten, en kreeg 31 Mei 1597 algemeene volmacht om voor hem op te treden, waarschijnlijk met het oog op relaties met Genua.

14 Augustus 1597 keerde Aernout aan boord van de Hollandia in het vaderland terug. Hij was van 9-16 Februari aan land geweest op Bali, en had over zijn verblijf aldaar aan zijn chef, den commies Jan Jansz Kaerel de jonge, een rapport overgelegd, dat hem als een

1) Bakhuizen van den Brink noemt hem ten onrechte Pieter. Studiën en Schetsen, p. 248.

2) Dr. Joh. Dyserinck in zijn verhandeling „De weerloosheid volgens de Doopsgezinden”, Gids 1890, D1 I, p. 132 noot, zegt daaromtrent: „Zeer bezwarend tegen dezen Amsterdamschen koopman als Doopsgezinde is hetgeen $\mathrm{Mr}$. $\mathrm{N}$. de Roever mij mededeelde, dat Lijntgens in Nov. 1596 ,gefailleerd” is. Men bedenke hierbij wel, dat de vaderen dit zulk een vergrijp achtten tegen de zedewet, dat zij den schuldige van de deelneming aan het avondmaal uitsloten". 
goed opmerker doet kennen en vele belangrijke bijzonderheden omtrent de gesteldheid van het eiland en zijn bewoners bevat. ${ }^{1}$ ) Zijn volledig reisverhaal is ongelukkigerwijze niet bewaard gebleven.

Kort na Aernout's thuiskomst verloor hij zijn moeder Elsgen Bartholomeusdr., die op 27 October in de oude kerk te Amsterdam begraven werd.

Zijn oudste zuster Margaretha verliet het ouderlijk huis, toen zij, oud 22 jaar, 2 Juni 1599, huwde met Anthony Moens. Zijn broeder Pieter de jonge, weduwnaar van Marie Tydemans, hertrouwde 2 Augustus 1603, met Leonora Braeckelman, en kwam bij zijn vader inwonen.

In het volgende jaar begon Koning Hendrik IV zijn pogingen bij de Staten Generaal om hun hulp te verkrijgen tot verwezenlijking van zijn lievelingsplan, het tot stand brengen eener handelsvaart op Oost-Indië. De gezant Buzanval diende in October het verzoek in om eenige Fransche kooplieden, welke dien handel wilden beproeven, behulpzaam te zijn bij den aankoop van schepen met bijbehoorende uitrusting en het aanwerven van schippers, stuurlieden en bootsvolk. Op 1 November ontving hij het vriendelijk, maar beslist antwoord, dat gaarne zou worden medegewerkt tot het aanschaffen van schepen, koopwaren en andere behoeften, maar dat geen hoop kon worden gegeven op het verleenen van toestemming tot het sluiten van eenige overeenkomst met een ingezetene dezer landen, met het doel op OostIndië handel te drijven. Daarin kon niet worden getreden, omdat de Staten gebonden waren door het octrooi der V. O. I. C., welke reeds met buitengewone lasten bezwaard was en met groote moeilijkheden te worstelen had.

In dit stuk werd de naam van geen Nederlandsch koopman genoemd, maar de onderhandelingen met Pieter Lintgens en zijn zoon Aernout waren toen waarschijnlijk reeds ver gevorderd, want twee maanden later, in het begin van 1605, ontving Prins Maurits een brief van den Koning, waarin deze personen, als voornemens om in Frankrijk ,een equipage” te doen naar Oost-Indië, ten warmste bij hem werden aanbevolen. De Prins deed daarvan mededeeling aan de Staten van Holland, die 12 Januari, onder den indruk van het groot nadeel, dat deze landen en de geheele handel op Oost-Indië zouden ondervinden en het groot voordeel dat voor den Spaanschen vijand

1) Dit rapport werd gepubliceerd door P. A. Leupe in de Bijdr. 1856, p. 203, vlg. 
zou voortvloeien uit een nieuwe concurrentie der Oost-Indische Conıpagnie van Fransche zijde, besloten met alle bekwame middelen den Koning van zijn voornemen terug te brengen. In het bijzonder zou de agent Aerssens te Parijs zich daartoe hebben in te spannen.

Den 20sten derzelfde maand werd hetzelfde schrijven in de StatenGeneraal besproken, met het gevolg, dat den Prins werd opgedragen, den Koning uiteen te zetten, dat hoe gaarne men hem ook ter wille zou zijn, dit hierbij onmogelijk was.

De Staten-Generaal hadden niet te veel gezegd, toen zij er op wezen, dat de Compagnie met ernstige bezwaren te kampen had. Haar moeilijkheden vermeerderden met den dag. De uitgaven, welke het krachtig voortzetten van den oorlog in Oost-Indië eischte, waren tot zoodanige hoogte gestegen, dat zij hare krachten te boven gingen en weldra den materieelen steun van de Landsregeering onvermijdelijk zouden maken. De vooruitzichten op winstuitkeering in de naaste toekomst waren zeer gering geworden. Nu kwam daarbij de concurrentie van een nieuwe Compagnie, die onder veel gunstiger voorwaarden, zonder oorlogslasten en onder bescherming der Fransche vlag zou kunnen werken. De schrik sloeg de aandeelhouders om het hart. De vijanden der O. I. Comp. en daaronder zeer bekwame, zooals Isaäc le Maire die 22 Februari 1605 zijn ontslag als bewindhebber had genomen, maakten van de gelegenheid gebruik om de onrust te vermeerderen. Vele participanten maakten bezwaar hun inleg verder te storten en zochten zich van hun aandeelen te ontdoen. De contramine had vrij spel.

Er waren ook deelhebbers, die hun aandeelen verkochten op grond van gemoedsbezwaren. De Doopsgezinden wenschten geen deel aan geld, waaraan bloed kleefde, en aan buit, die door geweld verkregen was. Tot de laatsten behoorden Pieter Lintgens en de zijnen.

Bewindhebbers hieven luide alarmkreten aan en weerden zich zoo goed zij konden. Zij dienden een uitvoerig protest in tegen de schending van het octrooi, en spaarden geen memories om de noodlottige gevolgen van het toegeven aan den wensch van Hendrik IV met klem van redenen uiteen te zetten.

Van de zijde van Lintgens dreigde het eerste gevaar. Er moest krachtig worden ingegrepen. Op hun aandrang besloten de Staten-Generaal 29 April 1605 Lintgens en zijn zoon op te roepen

1) Verg. Fruin. Een onuitgegeven werk van Hugo de Groot, Gids 1860, II, p. $34 \mathrm{vlg}$. 
om voor hen te verschijnen. Beiden kwamen 5 Mei in den Haag en vertoonden de commissie, die zij hadden gekregen van den Franschen Koning om de noodige uitrusting van schepen en scheepsvolk in deze landen gereed te maken. Maar het doel werd bereikt. De bijeenkomst eindigde met de verklaring van den ouden Lintgens, dat hij als landzaat en burger niet zou handelen tegen den wensch der Staten, terwijl hij beloofde niets tegen het octrooi der V. O. I. Compagnie te zullen ondernemen.

Hiermede was de zaak echter niet afgeloopen. Hendrik IV hield voet bij stuk. Den 30sten Augustus 1605 schreef hij weder aan Oldenbarnevelt, terwijl Buzanval werd aangespoord opnieuw alles in het werk te stellen om het doel te bereiken.

Dit geschiedde zonder twijfel op voortdurende aansporing van een Brabander Mathieu Coulhée, die van den beginne af als tusschenpersoon was werkzaam geweest. Hij kwam naar de Nederlanden en had 12 September een gesprek met Buzanval, die door zijn volkomen kennis van den toestand als gevolg van een langdurig verblijf in den Haag, persoonlijk overtuigd was van het mislukken van elke poging om de Staten van gevoelen te doen veranderen. Hij zelf zou een geheel anderen weg gevolgd en de Landsregeering buiten alles gehouden hebben. Indien Aernout Lintgens naar Frankrijk was gegaan en daarheen in stilte het benoodigde geleidelijk had laten overkomen, zou alles naar zijne meening op vreedzame wijze zijn verloop gehad hebben. Zooals hij het typisch uitdrukte: „c'est comme si nous voulions baiser la femme de notre voisin avec son aveu, qu'il nous prostituerait volontiers sous la couverture de son désaveu". Hij ging met Coulhée naar Oldenbarnevelt en mocht van dezen de vleiende woorden hooren, dat de vriendschap met Frankrijk hooger geacht moest worden dan het belang der O. I. Compagnie, maar daarbij den raad ontvangen niet verder aan te dringen, ook met het oog op de waardigheid van den Koning.

Buzanval kon Coulhée niet bekeeren en zag van verdere bemoeiingen met hem en Lintgens af. Hij beval aan Villeroy zijn eigen plan en daarbij de medewerking van een ander, veel bekwamer tusschenpersoon aan.

Inmiddels was Aernout Lintgens in dezelfde maand Sept. 1605 komen te overlijden. Hij schijnt als drinkebroer zijn leven geëindigd te hebben. Buzanval schrijft ten minste als hij zijn dood mededeelt „qui depuis est mort ici en beuvant". Hiermede kreeg de zaak van Lintgens een zwaren slag. Op dezen Aernout toch, die aan de eerste 
reis naar Indië deelgenomen had, waren groote verwachtingen gebouwd; hij was bestemd om als leider van de Fransche onderneming op te treden.

Bewindhebbers lieten ook daarna niets onbeproefd om den Koning tot andere gedachten te brengen. In overleg met de Staten Generaal gingen zij er toe over, om in November aan drie Fransche ministers een klein geschenk te vereeren. Maar ook deze poging ,tot vorderinghe van de saecke tegen de versochte equipage van Pieter Lintgens" werkte weinig uit. Hendrik ging door. Zoo kwam 17 April 1606 Buzanval weder met een schrijven van zijne hand van 3 Maart te voren, bij de Staten, inhoudende hetzelfde verzoek over de equipage van Lintgens. ${ }^{1}$ ) Er kwam eerst rust, toen de Staten, dit eindeloos andringen moede, op $1 \mathrm{Juli}$ een scherp plakkaat hadden uitgevaardigd, waarbij het octrooi der V. O. I. C. gehandhaafd werd, en zware straffen tegen de overtreders bedreigd werden, en op 8 September op dezelfde wijze aan alle scheepsvolk, piloten en andere ingezetenen dezer landen op straffe van verbanning en verbeurtverklaring van goederen, verboden hadden, zich buitenslands te begeven om te varen op Oost-Indië, anders dan met de Compagnie.

Uit Buzanval's brief van 27 September 1605 verneemt men, dat Lintgens een bedrag van 50000 Kronen in de O. I. C. had ingelegd, waarvan hij te juister tijd ${ }^{2} / 3$ zou hebben teruggetrokken. Op deze mededeeling berust het beweren, dat hij een zeer vermogend man geweest zou zijn.

Inderdaad blijkt uit het eerste, het eenige bewaard gebleven, deel van het Grootboek der actiën van de O. I. C. (1602-1607), dat Lintgens op 29 Aug. 1602 door tusschenkomst van den bewindhebber Jan Jansz Karel had ingeschreven voor $\mathrm{f} 60.000$, het grootste bedrag, waarvoor één persoon had deel genomen, en daardoor zonder twijfel grooten indruk gemaakt. Met de storting op deze inschrijving maakte hij echter geen haast; in Augustus en October 1603 had hij voor het eerst en te zamen f 15000 afbetaald. Op 30 April 1605, den dag nadat hij opgeroepen was om voor de Staten Generaal te verschijnen, was zijn aandeel teruggebracht tot $\mathrm{f} 30.000$, voor welke som hij als

1) Dyserinck vindt hierin aanleiding Lintgens te beschuldigen, zijn belofte te hebben geschonden, en dit hem als Doopsgezinde zwaar aan te rekenen. Het wil voorkomen, dat hier meer gedacht moet worden aan het onvermoeid aanhouden van Coulhée, zonder verdere ruggespraak met Lintgens. Het blijkt toch, dat deze in 1609 met de Staten, den Prins en Amsterdam op goeden voet stond. 
debiteur in het Grootboek bleef staan, terwijl daartegenover als afbetaald in zijn credit stond $\mathrm{f} 12923 .{ }^{1}$ )

Er was dus geen aanleiding hem op grond zijner participatie zeer vermogend te noemen. Het tegenovergestelde was in 1605 het geval, Lintgens zat in groote moeilijkheden en hij hoopte, dat de Fransche onderneming hem daaruit zou helpen. De gelegenheid was gunstig voor een eerlijk man als loon voor zijne diensten bij de behandeling der zaken en de aanschaffing van alles wat noodig was, goed geld te verdienen; voor iemand met een ruim geweten, zelfs zeer veel. Buzanval, die meende dat hij met Lintgens ,,et sa farine” met lieden van de laatste soort te doen had, vreesde het ergste en waarschuwde met klem er tegen, met hem in zee te gaan.

Men leert den financieelen toestand, waarin Lintgens in die dagen en later verkeerde, eenigszins kennen uit de hierachter besproken sententiën van het Hof van Holland.

In 1606 was Pieter de jonge gestorven. Zijn weduwe was in 1608 hertrouwd en vroeg de door haar bij huwelijksvoorwaarden bedongen douarie van 500 p. vl. op. De oude Pieter weigerde de uitbetaling. Gevolg was een proces, dat 30 Juli 1610 eindigde met een afrekening, waarbij hij o.m. 525 p. vl. ,voor $1 \frac{1 / 2}{2}$ jaar mondkosten” aan haar in rekening bracht voor den tijd, dien zij met haar man bij hem had ingewoond.

In October 1592 was Pieter Lintgens' broeder Mathijs overleden, nalatende twee kinderen, Mathijs de jonge en Lijsbeth. Als medeexécuteur testamentair deed Pieter het voorstel 1000 p. vl. uit de nalatenschap aan deze kinderen toekomende, voorloopig op interest uit te zetten, en toen dit geld behoorlijk terugbetaald was, hield hij het onder zich.

De jonge Mathijs, die in 1599 bij hem in huis kwam, werd door hem in December 1604 naar Genua gezonden ten einde met den boekhouder Mandekens voor de goede aflevering der lading van 7 schepen, bestaande uit tarwe, rogge, erwten en boonen, te zorgen. Ongelukkiger wijze werd Mandekens in 1605 bij een overval door bandieten doodelijk gewond. Diens exécuteur testamentair Christof fel Fortenbach nam daarop alle door Lintgens uitgezonden goederen ter waarde van 30.000 p. vl. in beslag, bewerende dat hij een aanzienlijk bedrag te vorderen had, en dat daarvoor ook de lading der schepen

1) Zie Bijlage II. Het vervolg van het Grootboek ontbreekt, zoodat niet is na te gaan, hoe Lintgens de liquidatie van zijn participatie heeft voortgezet. 
bij hem verbonden was. Onder deze omstandigheden keerde Mathijs naar Amsterdam terug.

Bevreesd, dat hij bij de erfenis van zijn vader te kort zou komen, drong hij op uitbetaling van het hem en zijn zuster toekomende aan.

Toen dit niet het gewenschte gevolg had, daagde hij zijn oom voor de bank van schepenen. 6 Maart 1609 werd het uit te keeren bedrag vastgesteld op f 8254 . Pieter beloofde te betalen, indien hij geld uit Italië ontving. Zijn neef weigerde daarin te berusten en eischte 13 Maart in rechten onmiddellijke voldoening. Nu volgde de toezegging, dat de schuld binnen 6 weken zou worden afgedaan.

Dit bleek Pieter onmogelijk en zoo besloot hij, 69 jaar oud, zelf naar Genua te gaan, om te zien wat hij van zijne zaken terecht kon brengen. Hij kwam daar in Mei 1609 aan, en bleef twee jaar uit, zonder iets te hebben bereikt, ondanks de aanbevelingen van de Staten Generaal, den Prins en burgemeesteren van Amsterdam. 2 Mei 1611 was hij te Amsterdam terug.

Zijn neef Mathijs was in 1610 gestorven, als erfgenamen achterlatende zijn moeder, Elisabeth van den Varent en zijn zuster Elisabeth, die daarop het huis, waarin Pieter gewoond had, de Wildeman, publiek wilden doen verkoopen. Anthonij Moens, gehuwd met Lintgens' oudste dochter, kwam voor zijn schoonvader op en slaagde er in een voorloopig accoord te maken. Overmits Pieter na zijn terugkeer echter in gebreke bleef te betalen, verleenden Schepenen 26 December 1611 verlof tot exécutie van zijn goederen, waaraan 6 Januari 1612 gevolg werd gegeven.

Van langeren duur was het verloop eener vordering, ingesteld door de erven van zijn factoor Hans Schopmans. Deze was sedert 1582 geplaatst te Malaga en aldaar in 1592 overleden. Onder zijn nalatenschap behoorde een bedrag van 11300 realen, dat volgens zijn uitersten wil aan zijn beide zusters moest worden uitgekeerd. Toen Lintgens weigerde daaraan te voldoen, werd hij door Hessel Lambrechtsz Brouwer, die met een der zusters gehuwd was, om betaling angesproken. Na diverse proceduren onderwierpen partijen in 1599 het geschil aan arbiters. Lintgens beweerde de opgeëischte som wel te hebben ontvangen, maar dat Schopmans hem een aanzienlijk hooger bedrag was schuldig gebleven. De erfgenamen konden dit beweren, bij gebrek aan voldoende bewijzen niet aanvechten, zoodat de uitspraak op 2 November 1599 te hunner nadeele uitviel. Zij berustten echter daarin niet. Overtuigd van de eerlijkheid van Schopmans stelden zij in Spanje een onderzoek in, waardoor zij tot 
de wetenschap kwamen, dat Lintgens ondeugdelijk gerekend had. Zij verzochten derhalve vernietiging van de arbitrale uitspraak en verkregen eindelijk dat Lintgens bij sententie van 14 Januari 1613 tot de betaling van de geëischte 11300 realen veroordeeld werd.

Als gevolg van deze beslissing sprak Hessel Brouwer Anthonij Moens voor deze som aan, bewerende, dat de verkoop van Lintgens' huis naar rechten niet had mogen plaats hebben. Hij stelde daarbij, dat Lintgens reeds in 1606 diep in schulden stak en notoirlick was geweest insolvent, en dat hij ,fraudulenter ende onbehoorlick sijne broeders kinderen hadde gegratificieerd". Het Hof ging echter bij sententie van 1 April 1615 met Anthonij Moens mede, die naar voren had gebracht, dat de schuld van Lintgens als voogd van weeskinderen de voorkeur had boven andere crediteuren en stelde dezen in het gelijk. Na zoovele jaren wachtens kwamen de erven Schopmans te laat; uit den insolventen boedel was niets meer te halen.

Een half jaar later den 3den October werd Lintgens in de Oude Kerk te Amsterdam begraven. Zijn levensavond is wel droevig geweest. 


\section{AANTEEKENINGEN. ${ }^{1}$ )}

1582.

Pieter Lintgens, koopman te Amsterdam heeft als factor te Malaga, Hans Schopmans, en te Sevilla Jacques Nicolaes. (Zie hieronder p. 158.)

1592. 18 September. Mathijs Lintgens, broeder van Pieter, benoemt dezen en Gilles de Witte, zijn zwager, tot uitvoerders van zijn uitersten wil. Mathijs was gehuwd met Elisabeth van der Varent, en liet twee kinderen na, een zoon Mathijs en een dochter Elisabeth. (Not. J. F. Bruyningh.)

1593. 7 October. Pieter Lintgens en 15 anderen machtigen Roemer Visscher en de compagnie van Ximenes, resideerende te Antwerpen, Lisbona en elders, wegens de polissen van assurantie op de schepen: de Leeman en de Appelboom, ten behoeve van Antoni Veluti te Jubelterra, ${ }^{2}$ ) etc. (Not. Lieven Heylinc.)

1594. 26 Maart. Hendrick Lintgens, oud 27 jaar, wonende in de Warmoesstraat, geassisteerd door Pieter Lintgens (zijn vader), ondertrouwt met Cornelia Spierinck van Rotterdam ,ende naer dien commissarissen gebleken is met de huwelijksche voorwaarden tusschen partijen, voor den notaris Balthasar van Baerle te Rotterdam gepasseerd”. (,Extraordinaris register" van personen, die te Amsterdam kwamen inteekenen, maar elders trouwden. Reg. 762 A, fol. 23.)

9 Augustus. Pieter Lyntgens, Jacques Bernard en Isaäc le Maire sluiten een contract van bevrachting met Jan Pietersen van Edam, schip 't Huys van Vrede, 50 1. naar de Condaet. (Not. J. F. Bruijningh.)

1595. 2 April. Aernout Lintgens, Pieter's zoon, gaat als adelborst met de eerste vloot naar Oost-Indië uit Texel zeil. (De Jonge, Opkomst II, p. 188 noot.)

1595. $10 \mathrm{Juli}$ Pieter Lintgens sluit contracten met 12 schippers. Zout laden te St. Vius. (Dit, evenals de volgende contracten, bij not. J. F. Bruyningh.)

1595. 14 Juli. Id. met Albert Frericx Coomans van Enkhuizen, schip de Bock, 85 1. Zout 1. St. Vius.

\footnotetext{
1) $\mathrm{Bij}$ het opsporen en bijeenbrengen dezer aanteekeningen heb ik in ruime mate de hulp ondervonden van mijn medewerker P. F. L. C. Lach de Bère te 's-Gravenhage en van den heer J. F. L. de Balbian Verster te Amsterdam, zoodat ik beiden grooten dank schuldig ben.

2) Gibraltar.
} 
1595. 11 Juli. Id. met Cornelis Claesz van Enkhuizen, schip de Jager, 56 1. naar de Condaet.

1595. 17 Juli. Id. met 4 schippers, zout 1. St. Vius.

1595. 24 Juli. Id. met Sijmon Claesz van Broek in Waterland, schip de Groene Leeuw, 85 1. Zout 1. St. Vius.

1595. 3 Augustus. Id. met Gerrit Hendriksz. van Enkhuizen, schip de Geldersche Bloem, 70 1. Granen laden in de Oostzee, waarmede naar-Frankrijk en Lissabon, retour met zout.

1595. 3 Augustus. Id. met nog 3 andere schepen.

17 Augustus. Verklaring van Pieter L., oud 55 jaar en Pieter Wiltbrae, oud 28 jaar, ten verzoeke van Jelle Pietersz. Blaeuwe, schipper v. d. Morgenstar, dat hij op verzoek en kosten van ettelijke kooplieden te Amsterdam, drie Portugeesche bootsgezellen, twee maanden geleden te Amsterdam aangekomen, die door de Engelschen gevangen genomen waren, ( 1 op de reis uit Indië en 2 bij Kaap Verde) aan boord genomen heeft om naar Portugal te brengen. (Not. J. Gijsberts).

1595. 10 October. Contract gesloten met Evert Alberts van Enkhuizen, schip de Haes, 601 . met waren en koopmanschap naar St. Lucas de Barrameda.

1596. 19 Juli. Hendrick Lintgens, koopman te Rotterdam, transporteert aan zijn vader Pieter, de goederen, door hem gezonden aan Jacques Nicolaes, koopman te Sevilla, voorts geld en goederen van hem elders in Spanje, alsmede lijwaet, berustende onder Adriaen Hendricksz ten Haeff. (Not. J. F. Br.)

1596. 7 September. Pieter L. sluit contract van bevrachting met Cornelis v. d. Wismer, schip 't Fortuyn, 60 1., granen naar Lissabon, laden in de Condaet, retour Amsterdam.

12 September. Id. met Sasken Jacobs, schip 't Fortuyn, 50 1., granen naar Lissabon, laden in de Condaet, retour Amsterdam.

1 October. Id. met Pieter Albert Roos van Amsterdam, schip de Roose, 80 1. Wijnen, enz. laden in Spanje.

11 November tot 5 December 1595 werden Pieter L. de volgende wissels aangeboden, die hij niet kon betalen. (Not. J. F. Br.)

11 November. Isaäc le Maire presenteert wissel Antwerpen, Arnout de Cordes, 520 p. vl.

Balthasar Coijmans id. Antwerpen, Arnout de Cordes, 676, p. vl.

Jasper Quinget id. Antwerpen, Arnout de Cordes, 936 p. vl. 
Thibout de Pickere presenteert wissel Antwerpen, Arnout de Cordes, 154 p. vl.

Harman Gorisz id. Middelburg, Adr. ten Haeff, 101 p. vl. Arnout Coubout id. Dantzig, Barent Gerritsz Wolterinck, 200 p. vl.

Hendrick Ruijter id. Hamburg, Lucas Beckeman, 8903/4 daalders.

Herman Rodenburg de j. id. Middelburg, Adr. ten Haeff, 189 p. vl.

Herman Rodenburg de j. id. Middelburg, Bernaert Adriaensz, 202 p. vl.

Philips v. d. Vinck id. Dantzig, Bar. Gerr. Wolterinck, 100 p. vl.

12 November. Frederick Claesz id. Dantzig, Bar. Gerr. Wolterinck, 314 p. vl.

Claes Fred. Rochga id. Dantzig, Bar. Gerr. Wolterinck, 86 p. vl.

Antonis Jansz. id. Dantzig, Bar. Gerr. Wolterinck, 138 p. vl.

14 November. Govert Dircx id. Dantzig, Bar. Gerr. Wolterinck, 200 p. vl.

18 November. Jacques Carbeels id. Dantzig, Bar. Gerr. Wolterinck, 200 p. vl.

21 November. Willem Geurtsen id. Hamburg, Lucas Beckeman, 700 daalders.

23 November. Jan Hermansz id. Dantzig, B. G. Wolterinck, 123 p. vl. 23 November. Jan de Vrije id. Middelburg, Adr. ten Haeff, 202 p. vl. 23 November. Adriaan du Gardijn id. Dantzig, B. G. Wolterinck, 100 p. vl.

27 November. Casper Grevenraat id. Dantzig B. G. Wolterinck, 110 p. vl.

27 November. Albert Bertherink id. Dantzig, B. G. Wolterinck, 52 p. vl.

28 November. Hans van Wesick id. Dantzig, B. G. Wolterinck, 300 p. vl.

28 November. Roelant Ernst id. Dantzig, B. G. Wolterinck, 82 p. vl.

28 November. Hendrick Ruijter id. Hamburg, Lucas Beckeman, 921/2 p. vl.

30 November. Adriaen du Gardijn id. Middelburg, Adr. ten Haeff, 187 p. vl.

30 November. Dirck Hendricksz id. Dantzig, B. G. Wolterinck, 100 p. vl.

2 December. Cornelis Jorisz id. Dantzig, B. G. Wolterinck, 200 p. vl. 
5 December. Salomon Voorknecht presenteert wissel Dantzig, B. G. Wolterinck, 400 p. vl.

30 November. Pieter L. machtigt onder overlegging eener lijst van zijne crediteuren, onderteekend door hem en zijn boekhouder Jaques Mandekens, en onder stellen van borgen: Govert Dircx Wuijtiers, Gerrit Jacobs Wilsen, Hans de Laat en Jaques Coijmans, ,die bekenden de commissie ten profijte van de gemeene crediteuren aengenomen en geaenvaert te hebben".

Als waarborg werden gegeven:, ,alle retouren van 't gene, dat buiten 's lands is, hetzij bij overcomste van schepen, waren en geld, welke in handen komen van de commissie, die zijne factoors in Zeeland en Antwerpen zullen mogen adviseeren en ordonneeren. Van de inkomsten zal den crediteuren betaald worden $+8 \%$ interest.

1597. 9-16 Februari. Aernout Lintgens op Bali.

23 Mei. Barent Gerritsz Wolterink, koopman te Dantzig, en Pieter Lintgens, koopman te Amsterdam, contracteeren met Sijmon Hillebrants, schipper op ,de Hope" naar Lissabon met tarwe aan Antonio de Coja en Garbrant Tol, factor van Pieter Lintgens (not. J. F. Br.).

31 Mei. Pieter L. geeft algemeene volmacht aan Jacques Mandekens, zijn dienaar, om in zijn naam allerlei zaken te doen (not. J. F. Br.).

14 Augustus. Terugkeer van Aernout L. uit Oost-Indië per Hollandia.

27 October. Begrafenis van Elsgen Bartholomeusdr., huisvrouw van Pieter Lintgens in de Wildeman (Warmoesstraat), 8 gld. 17 st. (Begrafenisboek van de Oude Kerk).

3 November. Pieter Lintgens met Arnout Hooftman, Jan Jacobsz Benningh, Hans Symonsz, Embert Pellicorne, Cornelis Gaillart, Jan le Greijn, Jan Jansz Carel, Jan Poppe, Berent Rutgers, Hans de Laat, Hans van Uffelen, Balthasar Coijmans, Thibout de Pickere, Gijsbrecht Bruijningh, Willem van Campen, Geen Symonsz, Jan van Baerle, Rombout Jansz, de weduwe van Hendrick Hudde, Elbert Luijtssen, Hendrick Meeussen, Jan Aux Brebis, Pieter Gerritsz Delff, Gerrit Gelmer, Sijmon Willemsz Moens, Willem van der Hoeven en Artus van Voorden, verzekeraars van diverse goederen in het schip ,het Paradijs”, dat gezeild was van Brazilië naar Venetië, aangesproken door Hans de Schot. (Not. L. Heijlinc, Hendrik Ottsen, p. XXV).

1598. 27 Januari. Hendrick en Pieter de jonge, zoons van Pieter Lintgens, machtigen Jan Thijsz te Dantzig (Not. J. F. Br.).

D1. 84. 
1599. 1 Maart. De weduwe van Cornelis de Vlamingh geeft met consent van Hessel Brouwer aan Pieter Lintgens een zak, waarin een werfboek, geintituleerd Boreador de la Vendera al año 1591 in Malga; een rekenboek beginnende: O. Arnoult Vantres Vesmode, Sevilla.

1599. 2 Juni. Anthony Moens van Haarlem lijwatier, oud 25 jaar, geassisteerd met zijn vader Lieven Moens, huwt met Margaretha Lijntgens, oud 22 jaar, geass. met haar vader Pieter Lintgens, Reg. 409, p. 177. (Als hare Ooms worden vermeld Anthonis Auckema en Barent Gerritsz Woltrink, not. J. F. Br. Reg. 172, fol. 203 v $^{\circ}$.)

1599. 27 December. Ten verzoeke van Pieter Lintgens attesteeren getuigen van wege Jacques Mandekens te Genua, omtrent ,de Roode Waterhont", schipper Thijs Bruijnsteen, geladen met rijst. (No. J. F. Br.)

1603. 2 Augustus. Pieter Lintgens de jonge, wonende in de Warmoesstraat, weduwnaar van Marie Tijdemans, trouwt met huwelijksche voorwaarden Leonora Braeckelman, wonende in den Haag. (Ondertrouw 9 Juli. Reg. 762, A. fol. 93.)

1604. 1 November. (Res. Staten Generaal). Op de remonstrantie van den Heer van Buzanval, overgegeven op last van den Koning van Frankrijk, ten faveure van eenige Fransche kooplieden, die den Oost-Indischen handel wilden beproeven, en daartoe geaccomodeerd worden met schepen, bootsvolk, piloten en andere commoditeiten, is na deliberatie geresolveerd; (in minute bewaard) ......

qu'estant permis aux subjects du Royaume de France (comme estant en bonne amitié avec les dites Provinces Unies) d'achapter en icelles pour leurs commodités aussy bien navires que aultres marchandises et commodités, comme il sera faict aux dits marchands en cet achapt toute amitié et adresse s'ils la demandent, sans toutefois que les dits Srs Estats leur scauraient ou peuvent donner aulcun espoir d'adresse pour en commencher aulcun nouveau traictè vers les Ost-Indes avec les habitants et subjects de ces pays, parce qu'il a esté promis aux marchants et participants en la compagnie des Ost Indes de ce pays, laquelle a été engagé avec un extrême travail, grandes despens et non sans beaucoup de contremines et factions dressées par l'ennemy contre cette union, qu'il ne sera ny faict ny attempté contraire aux capitulations et promesses, qui leur ont esté par eux faictes, prient partant les dits Srs Estats qu'il plaise au dict Sr. de Buzanval en faveur de ces estats et la dite Compagnie, montrant auprès sa dite Majesté qu'il veult accepter ceste 
respect(ueuse) et légitime excuse pour agréable .... Ainsy faict, etc. le premier de Novembre 1604.

1605. 12 Januari. (Res. Staten van Holland). Gelet op de brieven van den Koning van Frankrijk op het stuk van de navigatie en negotie op $O$. I. aan Z. Exc. geschreven, zoo aangaande Pieter Lyntgens en zijn zoon als anderszins, is verstaan: dat met alle bekwame middelen zal worden gearbeid, om Zijne $\mathrm{Maj}^{\mathrm{t}}$ te doen begrijpen, welk groot nadeel voor deze landen en den geheelen handel op O. I. tot voordeel van de vijanden het voorgestelde plan zou veroorzaken, en dat den agent Aerssens sérieuselijk zal worden gelast, om Zijne Maj ${ }^{\mathrm{t}}$, ,hetselve te dissuadeeren”.

1605. 20 Januari. (Res. Staten Generaal). Gelezen den brief van den Koning van Frankrijk aan Prins Maurits, ten faveure van Pieter Lyntgens en eenige kooplieden, die van plan zijn in Frankrijk een équipage te doen naar Oost-Indië, om aan dezen toe te staan eenige piloten en bootsvolk te werven, en nu de Prins verzocht, wat de Staten meenden, dat door hem daarop geantwoord zoude moeten worden, wordt besloten, dat Z. Exc. zou mogen terugschrijven, dat hem niets lievers zou zijn, dan Z. M. te believen, maar dat hij na overleg met de Staten, vast overtuigd is, dat de Koning van Spanje in deze zaak voorheeft, om het plan, dat de Staten bij de vereeniging van alle Compagniën hadden, te dwarsboomen, gevoelende deze Koning de groote schade die hij daardoor lijdt en het gevaar dat hij loopt den geheelen Oost-Indischen handel te verliezen.

Aangezien het zeker is, dat zonder het voortzetten van de vereeniging der compagniën de vaart en de handel op Oost-Indië moet ophouden, zooals dat vroeger door te groote concurrentie der verschillende compagniën gebleken is moet de oprichting van een nieuwe compagnie vermeden worden.

Bovendien vermogen de Staten tegen het verleende octrooi niets te doen, zonder de vereeniging te breken en een menigte van de voornaamste kooplieden dezer landen te ruineeren; dat Z. E. dus Z. M. zou verzoeken de Staten te excuseeren, en te dien einde te considéreeren, dat de Compagnie voortaan haar schepen ten oorlog zal toerusten om haar handel met geweld tegen het geweld en de macht van den koning van Spanje in Oost-Indië te vestigen en dezen aldaar alle mogelijke afbreuk te doen, waarvan de gepretendeerde Compagnie de profijten zonder kosten en perikel zou komen te genieten tegen alle redenen en recht.

1605. 16 Februari. P. Lintgens machtigt Gerhard de Rooij en Antonio Auckema, beiden te Middelburg. (Not. J. F. Br.) 
1605. 29 April. (Res. Staten Generaal.) Compareert Gedeputeerde O.I.C., geeft over sekere pointen tegen de poursuite, die Pieter Lijntgens bij den Coninck van Frankrijk is doende, tot nadeel van de Comp ${ }^{i e}$ en den dienst dezer landen, versoekende de Heeren Staten daarop met ernst te letten.

Besluiten: te schrijven aan Pieter Lijntgens, alzoo de Staten met hem hebben te communiceeren eenige zaken den dienst dezer landen aangaande, dat zịjn komst Woensdag e.k. gewenscht is.

1605. 5 Mei. Compareert Pieter Lintgens, koopman te Amsterdam, met zijn zoon, ,heeft d'heeren Staten tot Haer Hoog Mog. begeerte onderrigt van de impetratie in Vrankrijck van den Coninck bij sekere Françoisen van seker octroy omme aldaer te mogen oprichten eene Oost-Indische compagnie ende de schepen daertoe noodich alhier toe te rusten, ende daertoe oijck te lichten in dese landen piloten, schippers en schipsvolk, gelijck hij d'heeren Staten heeft ghetoont d'originele commissie op hem ende sijnen soone houdende mette conditie ende instructie daertoe dienende".

Verklarende niettemin, dewijl hij was een landzaat, daar het de heeren Staten zou ,misgenoegen” dat hij zich in de directie van deze zaak zoude bemoeien, dat hij willig was haar te laten rusten, vertrouwende dat, ingeval de Staten later de genoemde équipage zouden toelaten, zij goed zouden vinden, dat hij ,hem daerinne employere”. „Na lecture van alles is die comparant van de communicatie ende sijne gedane presentatie bedanckt, ende vermaent hem altijts te willen dragen, als een goed landsate ende borger van dese landen toestaet, sonder ijet tegen het octroij van de Vereenigde Oost-Indische Compagnie in dese landen te willen voornemen, dat hij belooft heeft".

27 Augustus. Remonstrantie O. I. C., waarin o. m. gewezen wordt op de groote uitrustingen welke in Portugal werden gereed gemaakt, en op 2 vloten, die reeds in Maart en April naar O. I. waren gezonden.

In een ander verzoekschrift hadden Bewindhebberen (want zij roerden zich zoo veel mogelijk) er o.a. op gewezen, dat in hun Compagnie, in tegenstelling met hetgeen in Spanje en Portugal geschiedde (waar de handel op Indië op zware straffen verboden was), plaats was voor allen, ook voor vreemdelingen, zoodat onder hare aandeelhouders Franschen, Engelschen, Brabanders, Vlamingen, Hanséaten en anderen geteld werden. Er bestond dus voor de Franschen geen noodzakelijkheid zelf op Indië te gaan varen. 
30 Augustus. Hendrik IV schrijft persoonlijk aan Maurits, Oldenbarnevelt en Buzanval.

Oldenbarnevelt antwoordde uitvoerig en herhaalde de bekende gronden voor het niet voldoen aan zijn verzoek. Hij werd daarbij pathetisch, toen hij de gruwelen beschreef, die de Portugeesen in Indië bedreven. „Gelijck zij luijclen in Amboina hebben bethoont, twelck zij overvallen, de ingesetenen vermoort, de swangere vrouwen opengesneden, die vruchten daaruit gehaelt, ende de mans daarmede int aensicht geslagen hebben, zeggende zulks te geschieden, omdat zijluijden mette Hollanders hadden gehandelt."

September. Aernout Lintgens overleden.

27 September en 19 October Brieven van Buzanval, hieronder gedeeltelijk afgedrukt.

Lettre à Monsieur de Villeroy du 27 Septembre 1605. ${ }^{1}$ )

Monsieur. Je vous escrivis hier estant à Rotterdam, d'où estant de retour en ce lieu, ${ }^{2}$ ) je leus celle du vingttroisiéme d'Aoust, tant l'orriginale que le duplicat d'icelle, venue avec votre dernière du onzième de ce mois, et le lendemain, j'eus icy le Brabançon, ${ }^{3}$ ) soliciteur de l'octroy pour Linkens; il estoit passé auparavant en ce lieu sans me voir pour aller sonder son fait et les partisans, qu'il a [à] Amsterdam. Je ne vous nierai point, que je me suis estonné de cequ'on s'a heurte si fort à cette pierre, laquelle j'avois préveu dès le commencement des achopemens; c'est pourquoy, j'avois dit dès son premier voyage au dit soliciteur, qu'il me sembloit qu'il prenoit cette affaire d'un mauvais biais et que je ne croyois pas que les Estats accordassent jamais à un leur bourgeois, et qui avoit part en la compagnie des Indes, de servir un Estat Etranger contre les promesses et contracts, qu'ils avoient faits avec ceux de la dite compagnie, lorsqu'ils la reunirent ensemble, et l'obligèrent non seulement au trafic, mais aussy à faire la guterre ès Indes aux Espagnols et Portugais, sans laquelle ils scavoient que ce trafic ne se pouvoit maintenir. Que mon avis seroit, que sans faire bruit il fit achapt de vaisseaux et retenues de pilotes et natelots, lesquels il envoyeroit à Havres de France, pour après les employer et faire prendre la route qu'il voudroit; que je ne faisois fort qu'on ne luy donneroit aucun empêchement en ce faisant; sur quoy il me dit, que tout son fait estoit fondé sur la personne du jeune Linkens, ${ }^{4}$ )
1) Kon. Bibl. en Rijksarchief.
2) 's-Gravenhage.
3) Mathieu Coulhée.
4) Aernout. 
qui avoit fait auparavant le dit voyage et qui depuis est mort icy en beuvant. Je lui repliquay que cet homme estoit libre et sans femme, se pouvoit couler doucement en France, et puis y estant se couvrir du commandement et protection de sa Majesté, ce qu'on ne molestast point pour son sujet son vieil père, qu'il auroit laissé à Amsterdam. Je luy offris par dessus le dit Linkens d'autres personnages, sous la conduite desquels, j'aimerois mieux risquer de mon argent que sous celle de Linkens, lesquels j'avois tellement pratiqués qu'ils me promettoient à aller servir le Roy en ce negoce, sans aucun respect ny permission des Estats. Il rejecta tout cela et dit qu'il vouloit Linkens comme le Phénix des Indes, que les Estats ne luy oseroient refuser sa demande, de laquelle toutefois il fut incontinant conduit ou plutost moy, quy la fis pour luy; de sorte que le remettant sur les premiers erres et ouvertures, que je luy avois faites, il les rejetta toujours brusquement sans beaucoup de raison, mais avec beaucoup d'importunités, à ce que je me voulasse roidir sur son désir, et prostituer en vain l'autorité de Sa Majesté, laquelle la Puce ${ }^{1}$ ) m'avoit prié apart d'épargner en ce sujet, que je n'y avancerois rien, et qu'ils feroient remontrer à Sa Majesté leurs raisons, qu'il esperoit qu'il trouveroit picquantes. Nonobstant cela ce soliciteur me harassa tant par ses impertinentes réponses qu'il faisoit à tout ce que je lui proposois, que je fus contraint enfin de lui dire qu'il me laissast en paix, et que puisqu'il il ne vouloit suivre mes avis, je serois bien aise, qu'il me déportât de son affaire en la quelle je suplirois Sa Majesté de n estre plus meslé. Depuis ce temps je n'y aurois plus songé jusques à cette dernière bourrasque, qui m'a un pe11 réveillé plus possible que l'xpériance qu'on a de moy ne mérite, mais il faut endurer de son maitre. Ayant donc reçu la lettre de Sa Majesté, je me suis efforcé à oublier tout le passé et ay voulu pour plus d'efficace mener ce soliciteur chez le Sieur de Bernefeld, bien qu'il voulut venir céans, auquel après qu'il luy eut présenté ses lettres, je luy tins des paroles sur ce sujet, que j'eusse retenues et gardées, si j'eus usé de mon propre sens. Le dit sieur nous repondit tout sur le champ, que par la nature de cet Etat et la raison cette demande ne se pouvait accorder sans ruiner la Compagnie des Ost Indes, et nous en dit tant de raisons que je ne veux vous ennuyer d'icelles.

1) Naam, waarmede Oldenbarnevelt wordt aangeduid: evenals met „la sauterelle” Prins Maurits, met „Bernabé” Hendrik IV, met „Egyptienne” Engeland, enz. 
Toutefois puisque mes paroles le réduisoient à cette extrémité, il nous dit librement qu'il estimoit moins dommageable à leur Etat de laisser perdre la dite compagnie que non par l'amitié du Roi, et que telle seroit son opinion en l'assembleé, mais que si Sa Majesté étoit bien conseillée, elle ne permettroit la ruine de la dite Compagnie, d'autant qu'elle se peut assuerer qu'icelle ruinée, ny les françoys, ni aucune autre nation ne pouront plus mettre le nez ès dicts Indes, à cause que les armes et les continuelles flottes de ce pays, tenant le dict traffic ouvert et tous les Roys orientaux respirant et souffrant sous la puissance d'icelles; les dites flottes venant à cesser, les Espagnols aussistost châtiront et subjugueront les dicts roijs et remettant leur autorité partout, fermeront plus étroitement que jamais la porte à tous ceux qui y voudront aborder. Nous vismes depuis le sieur Arsens ${ }^{1}$ ) à qui je recommanday l'affaire et luy dis qu'il la devoit affectionner pour effacer les impressions sinistres que l'on avait pris de son fils, pour s'y estre trop opposé. Il nous parla bien plus rondement on rudement, de sorte qu'il ètonna notre soliciteur des quatre pieds, qui m'en fit des plaintes non sans tordre et pervertir les paroles du dict seigneur pour m'aigrir. En quoy je reconnus qu'il y avoit de la malice en son fait et qu'il pouvoit bien m'en avoir pressé par de là. Voilà monsieur, notre premiere charge, nous verrons ce qui en arrivera quand nous viendrons au gros, et que la lecture des lettres du Roy et le rapport des languages que j'ay tenus, l'assemblée prendra quelque recès sur cette affaire, mais si ce qu'ils remontrent être vray ils ne nous pourront favoriser en ce poinct qu'à très grand regrès et comme par un désespoir. ${ }^{2}$ ) Cette Compagnie des Indes s'ébranle tous les jours. Elle a demandé tout de nouvean à ces messieurs ayde de douze vaisseaux de guerre pour se maintenir ès dicts Indes, autrement qu'elle n'en peut plus soutenir les frais sans secours du public. J'y ay quelque petite partie qui y trempe il y quatre ans, de la quelle depuis ce temps je n'ay pas tiré un seul escu. C'est ce grand intérest dont il est question. Chacun s'en retire, car ils nous mettent en compte tous les équipages de guerre, qu'ils sont contraints de faire pour maintenir ce trafic. Linkens le père

1) Cornelis Aerssens of Aerssen (1545-1627), vader van François van of d'Aerssen (1572-1641), eerst agent, later gezant te Parijs. N. Ned. Biogr. Wbk III, Leiden 1914.

2) Het volgende gedeelte tot „cabale que l'oblige à l'entreprendre" is afgedrukt bij Fruin. Gids 1860, II, p. 36. 
y avoit cinquante mille escus; il en a retiré ou vendu bien les deux tiers. Mais l'occasion principale qui l'a meu à ce faire est, qu' estant fort anabatiste, il improuve toute sorte de porte d'armes, soit offensives soit défensives et principalement les combats et prises, qui se sont faites par les flottes de ce pays sur les Portugais. Plusieurs de la mesme sorte se sont joincts à luy au dit Amsterdam, qui seroient bien ayse de dresser et pratiquer une compagnie en France, que ne seroit que pour le simple traffic, sans user d'hostilité ni de revanche sur les Espagnols et Portugais à cause de notre paix, cuidans par là laisser les combats et les proyes à ceux de ce pays, qui sont en guerre, et couler cependant sous la force de leurs armes et la faveur du nom français au profit des dits Indes. Et je croys qu'un des plus esseurés fonds sur lesquels ce soliciteur fonde sa société, quelque mine qu'il fasse, cest sur les dits anabatistes, car il n'auroit que faire du dit Linkens sans se sujet, à cause que c'est un vieillard, qui n'a jamais pratiqué les dits Indes. Et je voys maintenant, puisque nonobstant la mort de son fils, qui $\mathrm{y}$ avoit fait un voyage, il ne laisse pour cela de s'ingérer en cette affaire, qu'il y a quelque particuliere cabale qui l'oblige à l'entreprendre. ${ }^{1}$ ) Jay proposé à ce soliciteur Carlevy, ${ }^{2}$ ) qui est plus pratiqué en ce fait qu'homme que j'aye jamais veu comme ayant passé la plupart de son age ès Indes tant orientales qu'ocidentales et toujours, traffiquant. Il m'a promis de servir le Roy, si Sa Majesté le veut employer en ce fait, et qu'il trouvera moyen de dresser icy tout son équipage, sans faire bruit ou mettre ces gens en combustion les uns contre les autres, comme note soliciteur. Il est étranger, de sorte qu'il n'est point compris au contract que ces Messieurs ont fait avec ceux de la Compagnie des Indes. Pourquoy si nous avons tant d'énvie de faire jouir la France de ce traffic, n'employons nous une personne qui en a comme la clef et qui possible n'a point aujourd'hui son semblable en l'Europe en la connaissance de ces quartiers là. Monsieur, nous nous laissons emporter à des particuliers, qui veulent proffiter sur cette marchandise par les ressorts qu'ils y veulent faire jouer, et qui ne regardent point par un but général au bien du Roy, s'il n'est poursuivy par les moyens, dont ils espèrent tirer commodités particulières, aymant mieux permettre que tout un Estat se brouille, par l'éclaircissement du quel nous dépendons tant, que non pas de

1) Zie noot vorige bladzijde.

2) De nieuw voorgestelde tusschenpersoon. 
prendre les commodités, que nous en pouvons et voulons tirer doncement et sans le faire gémir. C'est comme si nous voulions baiser la femme de notre voisin avec son aveu qu'il nous prostituerait volontiers sous la couverture de son désaveu. Il me semble, Monsieur, que j'ay deu encore faire cet enuieux discours non pour eschiver le dernier commandement que j'ay et auquel je me porte entier et sans réplique, mais pour justifier mes précédentes actions, et faire paroitre que si j'ay failly, c'a esté par erreur et ignorance d'Etat et non par aveuglement d'aucun intérest particulier que je vous jure estre tout éloigné de moy en cette affaire, comme scait très bien ce soliciteur, qui a appris à Amsterdam les obligations que j'avois à la dicte compagnie, de sorte qu'il m'a bien sceu reprocher les peines que je prenais pour personnes si ingrates; mais il me connoist mal de penser qu'en mes actions j'aye autre but que celuy que doit avoir un homme de bien et d'honneur, qui consiste à mon avis à maintenir cet Etat en ionne intelligence et dévotion envers Sa Majesté. C'est trop parler d'un fait qui importe si peu au gros de nos affaires. Pour conclure donc ce propos je vous diray, que si ces Messieurs tiennent le voyage des Indes libre et ouvert, nous y entrerons mesme malgré eux; s'ils le laissent une fois fermer, nous en serons exclus quand bien nous serions aydés d'eux......

Lettre à monsieur de Villeroy du 19 Octobre 1605.

Monsieur! Tout ce qu'on a pu faire icy, je ne dis pas moy seul, mais mesme l'Etat tout ensemble pour accorder et accommoder le fait de Linckens au gré de Sa Majesté, a esté tenté en vain. La ville d'Amsterdam, c'est à dire le nerf de ce pays et la mère de la Compagnie des Indes, n'a janais voulu condescendre que son bourgeois triomphast au milieu d'elle de la dite compagnie, et en tirant les principaux émoluments et les fist passer par ses mains. J'ay veu cela dès le commencement que cette affaire fut prosposée, et le dis franchement à celuy qui l'a couroit par deça. Je ne vis jamais une si dure teste, car luy ayant fait ouverture d'autres moyens et meilleurs et nullement contentieux comme estait celuy de Linckens pour mettre le dit traffic en France, il n'y voulut jamais entendre; je ne m'en étonne pas maintenant depuis que j'ay découvert la proye, qui lai tomboit du bec et an dit Linckens et autres confrères, par le changement qui se faisait à 
l'entremise du dit facteur, qu'ils voulaient introduire à Amsterdam, pour la direction de leur fait. Mais cela ne m'importoit du tout rien, par tant que l'affaire se fust pu faire par ce moyen et eust esté très aise, qu'elle eust pris ce cours puisque telle estoit la volonté du Roy......

Je scay plus que si la direction de Linckens et de ceux de sa farine est suivie, qu'eux à la vérité y gagneront par et sur leurs provisions et le maniement qu'ils feront de l'argent de cette masse, mais je veux perdre cent pour cent si ceux qui y fourniront leurs deniers ne se trouvent trompés au moins de la moitié de leurs espérances et du compte qu'ils ont fait. Quand on viendra à la clôture d'iceluy le sus dit Carletty y entend d'autres finesses et veut croire que si on suit son avis et sa conduite qu'il aura d'autres proffits a faire que ceux que les Hollandais $\mathrm{y}$ font....

1605. 29 October. De Staten Generaal besluiten te vragen aan Bewindhebbers de waarde van de geschenken bestemd naar Frankrijk ,tot vorderinghe van de saecke tegen de versochte equipage van P. Lintgens". Zij geven daarbij in overweging zich niet te bepalen tot twee personen, maar ook een derde te gedenken.

2 November. Het antwoord was, dat de twee vergulde ledikanten zouden kosten ieder f 1600 en dat geen derde beschikbaar was, zoodat men zou onderzoeken ,twee schoone behancsels van camers oft anders" tot gelijke waarde te vinden.

3 November. De drie presenten zouden door Jan van der Veken aan zijn schoonzoon Aerssens in Parijs worden gezonden, bestemd voor de heeren Rosy, ${ }^{1}$ ) Sillery en Villeroi.

1606. 3 Maart. Hendrik IV schrijft op nieuw Buzanval aan om alles te doen, wat mogelijk is om de équipage van Lintgens te doen slagen.

17 April. Buzanval ${ }^{2}$ ) compareert bij de Staten Generaal en geeft den brief van den Koning over met hetzelfde gevolg als zijn vroegere pogingen.

$1 \mathrm{Juli} \quad$ Uitvaardiging van een scherp plakkaat, waarbij verboden werd naar Indië te varen en te equipeeren, behalve voor

1) Maximilien de Béthune, baron de Rosny (duc de Sully in 1606). Deze drie ministers hadden uit den buit van de Portugeesche kraak, door Heemskerck veroverd en in 1604 binnengebracht, damasten en porceleinen ten geschenke ontvangen. Les petits cadeaux, etc. Fruin, Gids 1860, II, p. 31.

2) Buzanval overleed 31 Aug. 1607 en werd begraven op 's lands kosten in het middenkoor der Groote of St. Jakobskerk te 's-Gravenhage. Zijn grafzerk is afgebeeld in de Ned. Leeuw 1902, p. 182. 
of op last van de Oost-Indische Compagnie. Overtreders zouden aan lijf en goed gestraft worden; ,ende sullen de gestatueerde penningen van de contraventiën verdeijlt worden, een derde deel daarvan tot behoeff van de voorsz Compagnie, het tweede tot behoeff van de armen ter plaetse daer de calenge sal geschieden en het derde tot behoeff van den officier die de calenge doen zal.

8 September. Bij plakkaat wordt aan alle scheepsvolk, piloten en andere ingezetenen dezer landen verboden zich in dienst te begeven of buiten 's lands om te varen naar O. I. dan met de Comp, die het octrooi heeft, bij pene van bannissement ten eeuwigen dage uit de Vereenigde Provinciën en confiscatie van goederen.

6 Mei. Pieter Lijntgens machtigt Christoffel Fortenbach te Genua, die door het overlijden van Jacques Mandekens zijn zaken is waarnemende (Not. J. F. Bruijnigh.)

30 Juni. Pieter Lijntgens, ook voor zijn zoon Salomon, benevens Anthoni Moens en Jan van Tongerloo als erfgenamen van Pieter Lijntgens de jonge, machtigen Gerard de Roij, koopman te Middelburg. (Not. J. F. Br.)

1607. 14 Februari. Pieter Lijntgens machtigt Gerard de Roij, zijn cosijn, te Middelburg. (Not. J. F. Br.)

1608. 18 Mei. Ondertrouw en trouw van Leonora Braeckelmans, wed. 9 Juni. Pieter Lijntgens de jonge, met Everhard Both van der Eem, subst. off. Hoogen Raad. Huwelijksakte, Reg. 409 fol. 77.

14 Juli. Pieter Lijntgens machtigt Dirk Boot om op te treden contra Leonora Braeckelmans. (J. F. Br.)

Uittrcksels uit de sententiën van het Hof van Holland.

I. Sententie 1610-95 en 96. Hof 622.

Den 8sten Februari 1603 was Pieter Lintgens, de jonge, in den echt getreden met Leonora Braeckelmans. Bij de huwelijksche voorwaarden was bepaald, dat zij bij zijn overlijden alles, wat bij hun huwelijk door haar was aangebracht, mocht behouden en een douarie van 500 p. vl. zou ontvangen. Haar man had van haar stiefvader Symon Havens bij die gelegenheid 100 pd. vl. gekregen.

De jonge Pieter stierf in 1606 zonder kinderen na te laten en zij bleef voorloopig bij haar schoonvader inwonen. De oude Pieter, optredende voor zijn zoon Salomon, benevens de beide schoonzoons Anthoni Moens en Jan van Tongerloo, hadden zich als erfgenamen gedragen o.a. doordien zij 30 Juni 1606 procuratie pas- 
seerden aan Gerard de Roy, om te Middelburg van bewindhebberen der V. O. I. C. te eischen hetgeen deze aan den jongen Pieter schuldig waren, met het gevolg dat uitbetaling verkregen werd.

Zij ontving echter geen geld, en begon, nadat zij in 1608 hertrouwd was met Everard Both van der Eem, substituut officier bij den Hoogen Raad (en weduwnaar van Abigaël Everard) een proces.

Pieter Lintgens beweerde, dat hij zich niet als erfgenaam beschouwde, doch dat hij zijn zoon belangrijke bedragen had voorgeschoten, zoodat deze hem bij liquidatie nog 1654 pd. vl. schuldig was gebleven. Bij den dood van zijn zoon had hij van diens weduwe de helft van dit bedrag te vorderen. Bovendien had zij koffers en meubelen van haar man laten wegbrengen, terwijl toch alles aan diens crediteuren behoorde. Hetgeen haar man bij huwelijksvoorwaarden had beloofd, ging hem niet aan, evenmin diens schuld aan Symon Havens.

Bij sententie dd. 30 Juli 1610, werd Pieter Lintgens veroordeeld de helft van $500 \mathrm{pd}$. vl., vermeerderd met den interest, aan haar uit te keeren. Van de geëischte 525 pd. vl. ,,voor $1 \frac{1}{2}$ jaar mondkosten ten zijnen huize door zijn zoon en diens vrouw genoten, werd hem bij het vonnis de helft toegewezen. Ook moest zij alle goederen, die zij uit het sterfhuis gelicht had, teruggeven. Anthoni Moens en Jan van Tongerloo werden denzelfden dag veroordeeld ieder $1 / 3$ van de helft van 500 pd. vl., vermeerderd met den interest, te betalen.

II. Sententie. 1615-65. Hof. 635.

Pieter Lintgens, voogd over de twee kinderen van zijn overleden broeder Mathijs, had het geld dier kinderen, 1000 p. vl., op interest uitgezet bij Gaspar Cooijmans, koopman te Amsterdam. Toen dit met den interest terugbetaald was, hield hij het onder zich.

Zijn neef Mathijs was in 1599 bij hem komen inwonen en werd in December 1607 naar Genua gezonden met 7 schepen door zijn oom geladen met tarwe, rogge, erwten en boonen. Hij moest aldaar samenwerken met Jaques Mandekens en zou de helft van de provisie genieten. In September 1605 werd Mandekens naar huis gaande 's avonds te 8 uur op straat door 4 rabouwen aangevallen en doodelijk gewond. Hij overleed na Christof fel Fortenbach tot uitvoerder van zijn uitersten wil te hebben aangewezen.

Deze Fortenbach nam alle goederen van Lintgens, waaronder de lading der 7 schepen, ter waarde van 30.000 
p. vl., in beslag, beweerende, dat Mandekens aan hem veel geld schuldig was en daardoor ook het aan Lintgens toekomende had verbonden.

Mathijs Lintgens keerde naar Amsterdam terug. Bevreesd door de verliezen van zijn oom in zijns vaders erfenis benadeeld te worden, drong hij op uitbetaling der penningen aan, en toen hij niet kreeg, deed hij zijn oom voor schepenen van Amsterdam een proces aan, dat 6 Maart 1609, leidde tot een accoord.

Pieter Lintgens zou aan zijns broeders kinderen uitkeeren 8254 gld, kon dit evenwel niet nakomen en beloofde voldoening, indien hij geld kreeg uit Italië. Zijn neef weigerde te wachten en sprak hem daarom 13 Maart weder in rechten aan. Hij beloofde toen binnen 6 weken te betalen, maar de termijn verstreek en de belofte kon niet worden nagekomen. Lintgens toch, ,,sijende dat sijne saecken in Italien nijet en worden bevordert ende noch gelt noch retour voor hem daer van daen en quam", is toen, ,selfs in sijn oude daegen vertrocken vuijt dese landen naar Genua", waar hij in Mei 1609 arriveerde. $\mathrm{Na}$ een tweejarig verblijf in Italië zonder eenig resultaat bereikt te hebben, keerde hij 2 Mei 1611 te Amsterdam terug.

In zijn afwezigheid was Mathijs gestorven, als erfgenamen, ieder voor de helft nalatende zijn moeder en zijn zuster. Deze wilden daarop het huis van Pieter Lintgens, de Wildeman, doen executeeren (24/12 1610 en 31/1 1611), waarop Anthoni Moens, gehuwd met Lintgens oudste dochter, considererende, ,dat het sulcx groote schande zoude wezen, dat deselve huijsinge boven zijn hooft (hij woonde in dat huis) vercocht soude worden bij openbare executie" 14 Januari 1611 in accoord met de erfgenamen trad. De laatsten transporteerden alle actie, die zij hadden op Pieter Lintgens, aan Anthoni Moens, waarbij borgen waren Lenert van Beecq en Gerrit Opheij, kooplieden.

Overmits Lintgens na zijn terugkeer in gebreke bleef de schuld te voldoen, verleenden schepenen van Amsterdam 29 December 161.1 verlof uitvoering te geven aan de executie van zijn goederen, waaronder het huis de Wildeman, dat door Moens werd ontruimd en 6 Januari 1612 in het openbaar verkocht.

Op de hiervan afkomstige penningen werd beslag gelegd door Hessel Brouwer. Bij het daarop gevolgde proces ,werd Moens in het gelijk gesteld, en Brouwer veroordeeld tot het betalen der proceskosten. 
III. Sententie $1606-75$, Hof 612 ; 1611-11, Hof 624; 1613-3, Hof 628.

In 1582 was Hans Schopmans door Pieter Lintgens als factor gezonden naar Malaga. Na een kort verblijf in het vaderland was Schopmans in 1589 naar zijn standplaats teruggekeerd, waar hij in 1592 ziek werd. Bij zijn testament benoemde hij tot zijn exécuteur testamentair en machtigde hij Jaques Nicolaes, mede factor van Lintgens te Sevilla. In afwachting van diens overkomst constitueerde hij Willem Claesz en Jacques de Vries om zijne zaken te behartigen. $\mathrm{Hij}$ had voor den notaris $\Lambda$ lfonso de Valentia te Malaga een lijst van debiteuren opgemaakt; aan hem persoonlijk behoorde een bedrag van 300 dukaten en 8000 realen van een schuld van Matheus de Lara te Malaga, groot 18725 realen (volgens bescheiden dd. 16 Juni 1592.) Bij codicil van 23 Juli 1592 bepaalde hij dat het hem toekomende, in total 11300 realen aan zijne erfgenamen, zijne beide zusters, moest worden overgezonden. Hij overleed denzelfaien dag. Jaques Nicolaes voldeed aan deze opdracht niet. Goederen, actiën en credieten werden door hem ten overstaan van den notaris geïnentariseerd, en alle boeken. papieren en gelden der verkochte koopmanschappen aan Pieter Lintgens overgemaakt. De echtgenoot van Aeffgen Schopmans, Hessel Lamberts Brouwer, kwam voor haar en haar zuster Trijntgen op en eischte van Lintgens uitkeering van de genoemde 11300 realen. Toen betaling daarvan geweigerd werd, wendde Brouwer zich in 1594 tot het gerecht te Amsterdam. Na verschillende proceduren onderwierpen partijen in 1599 het geschil aan de uitspraak van arbiters. Lintgens verklaarde na het overlijden van Schopmans wel geld te hebben ontvangen, maar beweerde dat dit de opbrengst was van door hem aan zijn factor gezonden goederen. Hij legde daarbij een rekening over van 4 partijen goederen in 1589 aan Schopmans toegezonden, ten bedrage van 36596 gld. inkoopsprijs, oploopende met alle onkosten, enz. tot 48596 gld. Van deze som zou Schopmans 29458 gld. verantwoord hebben, zoodat de erfgenamen nog 19.138 gld. schuldig bleven. Hiertegen konden deze geen bewijzen bijbrengen, zoodat de beslissing 2 October 1599 niet te hunnen voordeele uitviel, hetgeen Lintgens notarieel liet vaststellen. Om redenen in het proces vermeld moest hij $250 \mathrm{gld}$ betalen.

De erfgenamen berustten daar niet in. Hans Schopmans was - hetgeen Lintgens moest beämen - „,een suijnig 
jongman ende van geregeld leven, welken gedaagde (L.) voor date van 1589 veel hondert duijsenden betroude en van denselve behoorlicke rekening, bewijs ende reliqua gehadt hadde tot sijnen contentement". Zij schreven dus naar Spanje en lieten de zaak onderzoeken, waarbij verscheidene jaren verliepen. Ten slotte bleek, dat Pieter Lintgens ,ondeugdelijk" gerekend had.

Hessel Brouwer verzocht derhalve, thans onder overleggen van bewijzen, anuleering van de boven vermelde arbitrale uitspraak en uitbetaling van het hem competeerende. Aan dit verzoek werd bij sententie van 14 Januari 1613 gevolg gegeven, en Pieter Lintgens (wiens gemachtigde was Abraham Cabbeliau) door het Hof van Holland veroordeeld tot betalen van de 11300 realen, verhoogd met den interest tegen den pennning 16 van dato tot den dag van betaling toe,, verminderd met de reeds ontvangen 250 gld.

De uitspraak in dit proces was tweemaal uitgesteld: 31 Mei 1606 en 27 Januari 1611.

IV. Sententie 1615-65. Hof 635.

Hessel Brouwer had voor de erven van Hans Schopmans zijn proces om uitbetaling van 11300 realen, na jaren langen strijd 14 Januari 1613 gewonnen. Hij sprak nu Anthoni Moens, actionem cessam hebbende van de kinderen van wijlen Mathijs Lintgens voor het Hof aan. Daarbij bracht hij het volgende voor. Bij vonnis van het gerecht te Amsterdam van 24 Februari 1606 was Pieter Lintgens reeds veroordeeld te betalen aan Maerten Papenbroek 2606 p. vl. over en terzake van zekeren wisselbrief, door hem geaccepteerd en onbetaald gelaten, gelijk hij reeds in 1606 aan denzelfden schuldig gebleven was en onbetaald had gelaten een wisselbrief van 5000 kronen uit Genua teruggezonden, en nog vele duizenden ponden vl. in hetzelfde jaar aan verschillende personen schuldig was, in dier voege ,,dat denselven Pieter Lintgens all van voors. jaere 1606, notoirlick was gezueest insolvent ende de macht ende de middelen niet en hadde gehadt omme sijne crediteuren nae behooren te voldoen; oock soe dat hij sijn eijgen soon van sijn pretense moederlijcke goederen in ende op sijn Lijntges huijsinge ende metubelen, nijet hebbende connen voldoen, deselve van desen Hove gelicht hadde mandement, ende daermede gedaen dachvaerden soe hem Lintges als sijne crediteuren, ter eijnde omme met haere begonste executie te supercederen ende welcken nijet jegenstaende hij noch echter denselven sijnen soon van sijne pretensen nijet voldaen, 
maer fraudulenter ende onbehoorlick sijne broeders kinderen hadde gegratificeert", enz.;

dat in verband hiermede hij, Pieter Lintgens, geen schepenkennisse had mogen passeeren ten behoeve van zijn schoonzoon ter waarde van 30.000 car. guldens en evenmin aan zijn broeders kinderen een schuldbekentenis had mogen passeeren van 8254 gld., zooals hij gedaan heeft op 10 December 1608, en ook zich niet had mogen laten veroordeelen op 13 Maart 1609 voor schepenen te Amsterdam met een belasting van 8200 ten behoeve van die kinderen;

dit alles in fraude van hem eischer en de andere crediteuren en om met onbehoorlijke middelen zijn naaste vrienden voor anderen te gratificeeren, terwijl ook bevonden werd de voors. rekeningen ten eenenmale abusief en ondeugdelijk te zijn, en dat het transport en de cessie van de pretense schuld, door de kinderen van Mathijs Lintgens gedaan, naar rechten niet had mogen bestaan en dat derhalve de verkooping van Pieter Lintgens' huis door Anthoni Moens niet had mogen geschieden (als gevolg van de actionem cessam van de pretense schuld verkregen).

Anthoni Moens wierp hiertegen op, dat de schuld van Pieter Lintgens aan de kinderen van zijn broeder Mathijs was een preferente schuld als voogd over weeskinderen en dat toen deze niet betaald werd, de kinderen het recht en de voorkeur hadden boven andere crediteuren, en dat recht aan hem hadden afgestaan, waarom hij het huis ,dla Wildeman" had laten verkoopen.

Bij sententie van 1 April 1615 werd Moens in het gelijk gesteld.

1609. 12 Juni. (Res. S. G.) ,Sijn die kinderen ende bloedvrienden van Pieter Lijntgens den ouden, coopman tot Amstelredam (die zelf reeds vertrokken was), geaccordeerd brieven van voorschriften aen den hertoge ende senatoren van Genua, ten eijnde den voorschreven Lintgens mag worden geholpen ende overgestaan om te commen tot een goet cort recht ende expeditie van justitie, ende dat deselve hertoge ende senators hem ende sijnen soon willen nemen in haer protectie ende bescherminghe tegens alle gewelt encle moetwille.

Is voorts den voorschreven Pieter Lijntgens den oude ende sijne soon ${ }^{1}$ ) geaccordeert pasport van de heeren Staten en recommandatie omme deselve alomme, des noot zijnde, tot derselver voerstant te mogen gebruijcken."

1) Den jongsten, Salomon. 
Denzelfden dag zonden de Staten hun aanbeveling in het Italiaansch, geteekend door Oldenbarnevelt.

Ook de regeering van Amsterdam, schreef naar Genua, dat Pieter Lijntgens, over de 70 jaren oud, over kwam voor zaken met Christoffel Fortenbach en vroeg medewerking.

15 Juni. Prins Maurits deed hetzelfde en deelde mede, dat het te goed van Lijntgens op een aanzienlijk bedrag werd geschat, en dat dit, nadat Mandekens gekwetst en overleden was, in handen was gekomen van Chr. Fortenbach ,,comme curateur et administrateur de la maison mortuaire dudit Mandekens. ${ }^{1}$ )

1611. 13 Maart. Lenert Hofman (Horsman?) huwt met Lijsbeth Lintgens, geb. 1588, dochter van Matthias Lintgens. (Not. J. F. Br.)

1614. 28 Februari. Pieter Lijntgens machtigt zijn schoonzoon Anthoni Moens om op te treden in zake vordering Hessel Brouwer. (Not. J. F. Br.)

1616. 3 October. Pijetter Lijntges, wonende achter dije Suijderkerck, ende begraven op het hooch koor (Kosten 16 gld.) Begr. reg. van de Oude Kerk.

Den 21sten October 1597 bij den dood zijner vrouw kocht Lintgens een graf van de erfgenamen van Angenita Lubberts. Den 16en December 1614 verkocht hij het weder aan zijn schoonzoon Antoni Moens. Hij zal in hetzelfde graf zijn bijgezet. (Archief van de Hervormde Kerken, N. Z. Kapel te Amsterdam).

1622.

Anthonio Moens Lievensz, weduwnaar van Margaretha Lijntgens Pietersdr., wonende te Amsterdam op de Heerengracht hertrouwt met Sara Tongerloo, weduwe Jan Jansz Munter. (Elias, Vroedschap II, p. 625, 626.)

1) Vergl. Dr. K. Heeringa. Bronnen Levantschen handel. Den Haag, 1910, D1. I, p. $50 \mathrm{vlg}$. 


\section{Pieter (de oude)}

geb. \pm 1540

$\dagger$ A'dam, begr. O. K. 3/10 1616.

$\mathrm{Hij}$ noemde neef (oomzegger):

Gerard de Roij 14/2 1607.

$X$

Elsgen Bartholomeus dr.

$\dagger$ A'dam, begr. O. K. 2/10 1597.
1. Hendrik gb. 土 1567 $X$ (h. v. w. not. Bal. thazar van Baerle) R'dam nà 26/3 1594

Cornelia Spierinck.

3. Aernout
gb. $1571-1572$
+ Sept. 1605.

4. Margaretha gb. 1577

(de joter

† 1606 vóór 30/6

$\times 10$ Maria Tijdemans

$2^{\circ}$ (h. v. w. $2 / 81602$ )

Leonora Braeckelman

zij hertr. 's G'hage

$$
\text { 18-5 }
$$

9-6 Gr. Kerk 1608

Everardt Both v. d. Eem

subst. officier Hooge Raad

wedr. van Migael Everard

(geh. 's G'hage 5/11 1603.) dr.

van den pred: Pieter Everard.
2. Matthijs (de oude)

† Oct. 1592

Elisabeth van de Varent

test $^{\mathrm{n}} \quad 18 / 91592$.

Hare zwagers gend: Gillis de Witte 1592 Willem de Camp 1611. 
GROOTBOEK v/d. O. I. ACTIEN ${ }^{1}$ )

$1602-1607$

Kol. a rchief

10670

(p. 154).

Pieter Lijntgens is schuldich den 29 Augusti anno 1602 aen capitael per Jan Jansz

Carel van wegen ditto Lijntgens getekent . . . . . . . . . . . . . . 60000.-

Adi 22 Julij 1603 aen Carel Lijbaert tot Santwitz p. ditto Lijntgens geaccepteert 1500.-

9 April 1605 aen Jasper Quinget per transport uijt d'overgesch. betalingen 900.ditto aen Michiel Boonaert , , , , , , \#

ditto aen Pieter Jacobsz van Rijn , , , , , , , , , $\quad$ 500.

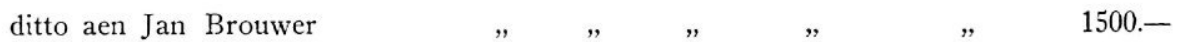

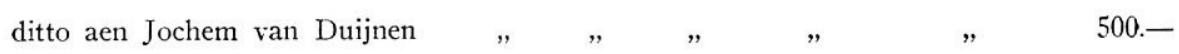

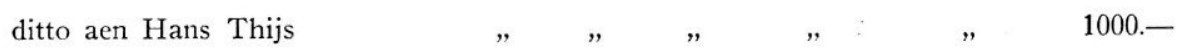

ditto aen Wolphert van Bijlaer , , , , , , , , , ,

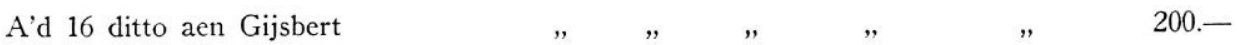

ditto aen Mr. Cornelis Baccaert , , , , , , " , 200.-

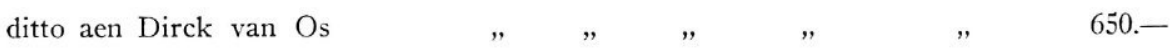

ditto aen Cornelis Adriaen Jobsz , , , " , , " , $\quad$ 800.-

30 ditto Aen hem selven voor dat bij des rekeninghe bevonden wert bij ditto

Pr. Lijntgens betaelt te wesen op rekeninge van 30000 gl. over-

gedraghen, folio . . . . . . . . . . . . . . . 513 12923.-

somma f 81923 -

1) De actiën moesten worden volgestort in drie gelijke termijnen op 1 October der jaren 1602, 1603 en 1604 . Over het ontbrekende zou $8 \%$ rente berekend worden. 
Pieter Lijntgens moet hebben den 23 Augusti anno 1603 van cassa op rekeninge van d'overges. somme betaelt . . . . . . . . . . . . . . . . . 3562-12-0

Ad. 28 Augusti a 1603 van cassa op rekeninge van d'overges. somme bet. . 5437-8-0

21 Octob. $\mathrm{a}^{\circ} 1603 \quad, \quad, \quad, \quad, \quad, \quad, \quad, \quad, 6000-0-0$

15 Jan. 1604 Van de Camer tot Amsterdam p. transp. van d'actie van . . 1500_,,-,

9 April 1605 van Jaspar Quinget p. transp. van d'actie van 3600 gl. 3600-,,-,

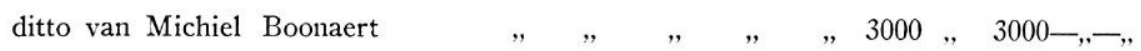

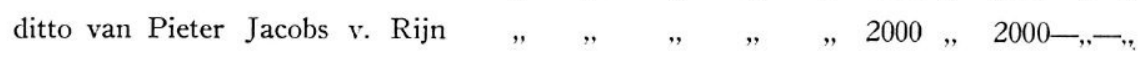

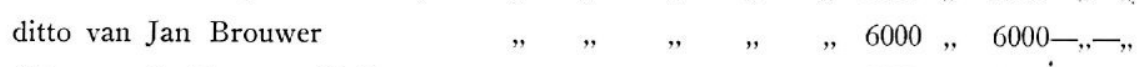

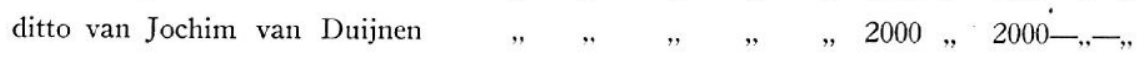
ditto van Hans Tijs $\quad$, , , , , , , $4000 \quad, \quad 4000-,$, , ditto van Wolphert van Bijlaer , , , , , , , 2000, , 2000-,,-,

15 ditto van Cassa voor rekeninghe van $1 / 3$ bet per Jan Brouwer . . . 1060-,,-, 16 ditto van Gijsbrecht van Loon p. transp. van d'actie van 800 gl. 800 -.,-,

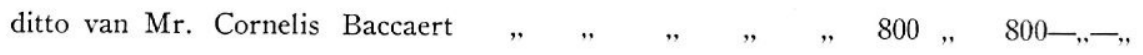

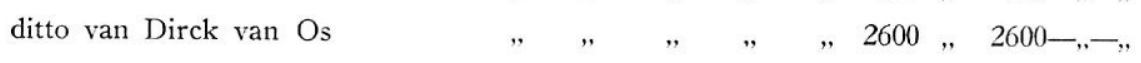
ditto van Cornelis Adriaen Jobsz , , , , , , , $3200 \quad, \quad 3200-,,-$,

27 ditto van cassa voor rekeninge van $1 / 3$ per Pr. Jacobsz v. Rijn betaelt 620-.,-,

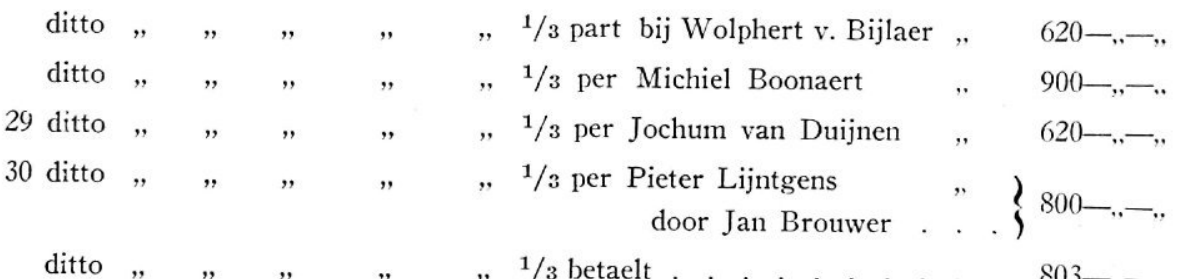
ditto $" \quad, \quad=\quad{ }^{1 / 3}$ betaelt . . . . . . . . . . 803-,, -, Ditto van hem selven omme desen te sluijten voor dat Pieter Lijntgens bij dese rekeninghe bevonden wert te participeren met de somme van 30000 gld., die overgedragen is folio. . . . . . . . . . . . 51330000 -, , , somma f 81923-..,., 